\title{
Arbeidsmarktperspectieven voor meisjes en allochtonen
}

Citation for published version (APA):

Vlasblom, J. D., de Grip, A., \& van Loo, J. B. (1997). Arbeidsmarktperspectieven voor meisjes en allochtonen. Researchcentrum voor Onderwijs en Arbeidsmarkt, Faculteit der Economische

Wetenschappen. ROA Reports No. 9 https://doi.org/10.26481/umarep.1997009

Document status and date:

Published: 01/01/1997

DOI:

10.26481/umarep.1997009

Document Version:

Publisher's PDF, also known as Version of record

\section{Please check the document version of this publication:}

- A submitted manuscript is the version of the article upon submission and before peer-review. There can be important differences between the submitted version and the official published version of record.

People interested in the research are advised to contact the author for the final version of the publication, or visit the DOI to the publisher's website.

- The final author version and the galley proof are versions of the publication after peer review.

- The final published version features the final layout of the paper including the volume, issue and page numbers.

Link to publication

\footnotetext{
General rights rights.

- You may freely distribute the URL identifying the publication in the public portal. please follow below link for the End User Agreement:

www.umlib.nl/taverne-license

Take down policy

If you believe that this document breaches copyright please contact us at:

repository@maastrichtuniversity.nl

providing details and we will investigate your claim.
}

Copyright and moral rights for the publications made accessible in the public portal are retained by the authors and/or other copyright owners and it is a condition of accessing publications that users recognise and abide by the legal requirements associated with these

- Users may download and print one copy of any publication from the public portal for the purpose of private study or research.

- You may not further distribute the material or use it for any profit-making activity or commercial gain

If the publication is distributed under the terms of Article $25 \mathrm{fa}$ of the Dutch Copyright Act, indicated by the "Taverne" license above, 


\section{Arbeidsmarktperspectieven voor meisjes en allochtonen}

ROA-R-1997/9

Jan Dirk Vlasblom

Andries de Grip

Jasper van Loo

Researchcentrum voor Onderwijs en Arbeidsmarkt

Faculteit der Economische Wetenschappen en Bedrijfskunde Universiteit Maastricht

Maastricht, november 1997 
ISBN 90-5321-216-7

SEC97142.wp7/AdG 


\section{Inhoud}

\section{Bladzijde}

Voorwoord

Samenvatting $\quad$ ii

1 Inleiding 1

2 Algemene indicatie arbeidsmarktperspectieven in 2002

3 Arbeidsmarktperspectieven voor meisjes $\quad 5$

4 Ontwikkelingen in deeltijdwerk 14

5 Arbeidsmarktperspectieven voor allochtonen $\quad 21$

$\begin{array}{ll}6 \text { Conclusies } & 27\end{array}$

$\begin{array}{ll}\text { Enkele centrale begrippen } & 30\end{array}$

$\begin{array}{ll}\text { Literatuur } & 32\end{array}$

$\begin{array}{ll}\text { Bijlage } 1 & 33\end{array}$ 


\section{Voorwoord}

De in dit rapport geanalyseerde arbeidsmarktinformatie is ontleend aan het Project Onderwijs-Arbeidsmarkt, waarover integraal is gerapporteerd in De arbeidsmarkt naar opleiding en beroep tot 2002 (ROA-R-1997/7) en de bijbehorende Statistische Bijlage (ROA-R-1997/7B). De analyses waarover hier wordt gerapporteerd zijn verricht in opdracht van de Directie Bestuursondersteuning en Advies van het Ministerie van Onderwijs, Cultuur en Wetenschappen. 



\section{Samenvatting}

Om inzicht te krijgen in de achterliggende oorzaken van ongelijke arbeidsmarktperspectieven voor verschillende groepen is het van belang om te weten in hoeverre deze groepen zich op verschillende arbeidsmarktsegmenten bevinden. Als dat zo is, is het in het kader van het emancipatiebeleid mogelijk via de opleidings- en beroepskeuze iets te doen aan de relatieve achterstand van bepaalde groepen. Vanuit deze invalshoek wordt in dit rapport een overzicht gegeven van de arbeidsmarktkansen van meisjes en allochtonen gerelateerd aan hun opleidingsachtergrond. Daarnaast is het in het kader van een meer gelijke verdeling van betaalde en onbetaalde arbeid tussen jongens en meisjes van belang om te weten in hoeverre er verschillen bestaan tussen meisjes en jongens met betrekking tot de mogelijkheden om, gezien hun opleidings- en beroepskeuze, hun betaalde arbeid in deeltijd te verrichten.

Met betrekking tot de arbeidsmarktperspectieven van meisjes blijkt dat voor de opleidingstypen en beroepen waar meisjes in de meerderheid zijn, de verwachte arbeidsmarktperspectieven voor de komende jaren goed zijn. Ook de conjunctuurgevoeligheid van de werkgelegenheid voor die opleidingen en beroepsgroepen is relatief laag. Wel blijkt dat ook de mogelijkheden die dergelijke "meisjesopleidingen" bieden om in een ander dan het nauw bij de opleiding aansluitende beroep een baan te vinden laag zijn. Dit betekent dat wanneer er op een gegeven moment sprake is van een krimpende werkgelegenheid in deze beroepen, meisjes met deze opleidingsachtergrond het risico lopen dat ze in het geheel geen werk meer kunnen vinden.

Wanneer de mate waarin deeltijdwerk voorkomt bij de opleidingen waarin vrouwen in de meerderheid zijn vergeleken wordt met de mate waarin in deeltijd wordt gewerkt in de opleidingstypen waar mannen in de meerderheid zijn, dan blijkt dat bij de typische "meisjesopleidingen" deeltijdwerk een veel vaker voorkomend verschijnsel is dan bij de typische "jongensopleidingen". Wel is het zo dat ook voor een groot aantal "jongensopleidingen" de mate waarin deeltijdwerk voorkomt een stijgende tendens vertoont. Ook bij de "meisjes- beroepen" komt deeltijdarbeid veel vaker voor dan bij de "jongensberoepen". Maar ook voor de "jongensberoepen" geldt dat deeltijdwerk steeds vaker voorkomt.

Met betrekking tot het arbeidsmarktperspectief van de allochtonen wordt in dit rapport aangegeven dat vooral de VBO-opleidingen door relatief veel allochtonen gevolgd worden. De arbeidsmarktperspectieven van deze opleidingen zijn vaak matig of slecht, met als gevolg dat de verwachte arbeidsmarktperspectieven voor allochtone schoolverlaters achterblijven bij die van de autochtone schoolverlaters. Wel blijkt dat de allochtone meisjes een iets beter arbeidsmarktperspectief hebben dan de allochtone jongens. Dit is opmerkelijk, omdat binnen de totale groep schoolverlaters juist de jongens een iets beter perspectief hebben. 


\section{Inleiding}

Om inzicht te verkrijgen in de achterliggende oorzaken van ongelijke arbeidsmarktperspectieven voor verschillende groepen is het van belang om te weten in hoeverre deze groepen zich in verschillende arbeidsmarktsegmenten bevinden. In dit rapport wordt een dergelijke analyse uitgevoerd voor een tweetal doelgroepen van het emancipatiebeleid, te weten vrouwen en allochtonen. Beide groepen hebben op de arbeidsmarkt een minder gunstige positie. Dit blijkt bijvoorbeeld uit het werkloosheidspercentage voor vrouwen dat op 7,8\% ligt, terwijl de werkloosheid voor mannen $5,9 \%$ bedraagt (CBS, 1997a). De positie van allochtonen is nog zwakker, wat ook blijkt uit het bijzonder hoge werkloosheidspercentage van 18\% (CBS, 1997b).

In dit rapport zal worden nagegaan in hoeverre de opleidingsachtergrond van meisjes en allochtonen en het beroepsdomein waarin zij werken van invloed is op hun toekomstige arbeidsmarktpositie. Eerst zal een beeld worden geschetst van de arbeidsmarktperspectieven voor de opleidingen waarvan het merendeel van de uitstroom van schoolverlaters door meisjes wordt gevormd. Ook zal een overzicht worden gegeven van de beroepsgroepen waarin het grootste deel van de werkenden vrouw is. Hierbij zal niet worden ingegaan op de mate waarin de verdiende inkomens vrouwen in staat stellen economisch zelfstandig te zijn. Als deze opleidingen en beroepsgroepen qua arbeidsmarktperspectief afwijken van het gemiddelde beeld, is dit een verklaring voor de verschillen in arbeidsmarktperspectieven tussen jongens en meisjes. Een verklaring, die tegelijkertijd ook een eerste indicatie kan zijn in welke richting een meer gelijke arbeidsmarktpositie tussen jongens en meisjes door studie- en beroepskeuze bewerkstelligd zou kunnen worden.

Ook zal in dit rapport een overzicht gegeven worden van de mate waarin deeltijdwerk voorkomt, gerelateerd aan opleidings- en beroepskeuze van mannen en vrouwen. Op deze wijze wordt inzicht gekregen in de mogelijkheden om te komen tot een meer gelijke verdeling van onbetaalde zorgtaken en betaalde arbeid tussen mannen en vrouwen. Het is daarvoor immers noodzakelijk dat er mogelijkheden tot deeltijdwerk bestaan.

Behalve aan de arbeidsmarktpositie van meisjes en de mogelijkheden voor jongens en meisjes om in deeltijd te werken, wordt in dit rapport ook aandacht besteed aan de positie van een andere doelgroep voor emancipatiebeleid: allochtonen. Op dezelfde wijze als dat voor de meisjes is gedaan, zal een beeld worden gegeven van de arbeidsmarktperspectieven van de opleidingen die vaak door allochtonen worden gevolgd. In dit rapport zal de positie van de allochtonen geschetst worden aan de hand van de arbeidsmarktperspectieven van de door hen gevolgde opleidingen. Hierbij is er impliciet van uit gegaan dat werkgevers uitsluitend kijken naar de opleidingsachtergrond van een werkzoekende, en niet naar andere kenmerken zoals geslacht en etniciteit. Er wordt dus bij de bespreking van de arbeidsmarktperspectieven geen aandacht geschonken aan het probleem van discriminatie van allochto- 
nen. Een overzicht van arbeidsmarktkansen van allochtonen dat wel expliciet met dergelijke aspecten rekening houdt, vereist een ander soort studie ${ }^{1}$.

De indeling van dit rapport is als volgt: hoofdstuk 2 geeft een beeld van de arbeidsmarktperspectieven van de beide doelgroepen van het emancipatiebeleid in het algemeen. In hoofdstuk 3 wordt een indicatie gegeven van de arbeidsmarktperspectieven van meisjes, gerelateerd aan respectievelijk hun opleidingskeuze en beroepskeuze. Naast de op middellange termijn verwachte arbeidsmarktperspectieven van de verschillende opleidingstypen, zal ook worden ingegaan op de meer structurele kenmerken van de arbeidsmarktpositie van de opleidingen. Hierbij zal met name worden gekeken naar de conjunctuurgevoeligheid van de werkgelegenheid en de uitwijkmogelijkheden naar verschillende beroepen. Hoofdstuk 4 bevat een overzicht van de mate waarin deeltijdwerk voorkomt, gerelateerd aan opleidings- en beroepskeuze van jongens en meisjes. In hoofdstuk 5 wordt een overzicht gegeven van de arbeidsmarktperspectieven van allochtone jongeren, gerelateerd aan hun opleidingskeuze. Hoofdstuk 6 bevat een samenvatting en enkele conclusies.

1. Zie hiervoor b.v. Van Beek (1993) 


\section{Algemene indicatie arbeidsmarktperspectieven in 2002}

In dit hoofdstuk wordt een indicatie gegeven van de verschillen in arbeidsmarktperspectieven van schoolverlaters in het jaar 2002, verbijzonderd naar geslacht en etniciteit. Deze indicatie is gebaseerd op de Indicator Toekomstige Arbeidsmarktperspectieven (ITA). Deze indicator geeft voor elk opleidingstype de verhouding aan tussen enerzijds het aantal baanopeningen en anderzijds het aantal schoolverlaters en kortdurig werklozen ${ }^{2}$. Door een gewogen gemiddelde te nemen van de ITA's op basis van de opleidingsachtergrond van de schoolverlaters uit een bepaalde doelgroep, kan een gemiddelde waarde van de ITA verkregen worden voor de desbetreffende doelgroep. Tabel 2.1 geeft een algemene indicatie van de gemiddelde arbeidsmarktperspectieven op basis van de opleidingsachtergrond van de schoolverlaters, verbijzonderd naar geslacht en naar etniciteit ${ }^{3}$. Binnen de groep allochtone schoolverlaters is ook de verbijzondering gemaakt naar geslacht.

Tabel 2.1

Indicator Toekomstige Arbeidsmarktperspectieven (ITA) in 2002 naar geslacht en etniciteit

\begin{tabular}{lll}
\hline & ITA & Typering \\
\hline meisjes & 0,99 & goed \\
jongens & 0,98 & goed \\
allochtonen & 1,02 & redelijk \\
autochtonen & 0,99 & goed \\
allochtone meisjes & 1,01 & redelijk \\
allochtone jongens & 1,03 & redelijk \\
\hline
\end{tabular}

Bron: ROA

Uit de tabel blijkt dat voor alle onderscheiden groepen de verwachte arbeidsmarktperspectieven, gemiddeld genomen, redelijk tot goed zijn. Daarbij zijn er echter wel verschillen. Voor de schoolverlaters die de komende jaren op de arbeidsmarkt zullen instromen, geldt dat jongens door hun opleidingsachtergrond gemiddeld genomen een iets beter arbeidsmarktperspectief hebben dan meisjes. Ook geldt dat autochtone schoolverlaters een iets beter perspectief hebben dan allochtone schoolverlaters. Echter, opmerkelijk genoeg hebben binnen de groep allochtone schoolverlaters juist

2. Achterin dit rapport is een verklarende lijst opgenomen van een aantal centrale begrippen.

3. Daarbij is gebruik gemaakt van de beschikbare schoolverlatersgegevens uit de RUBSenquête en de HBO-Monitor (ROA, 1997a). Deze gegevens hebben overigens alleen betrekking op de schoolverlaters van het AVO, VBO, MBO en $\mathrm{HBO}$. 
de meisjes door hun opleidingsachtergrond een iets beter arbeidsmarktperspectief dan de jongens ${ }^{4}$.

4. Zoals gezegd gaat het hier slechts over verschillen in de gemiddelde arbeidsmarktperspectieven tussen de onderscheiden groepen schoolverlaters. In hoofdstuk 2 zal meer specifiek worden ingegaan op de arbeidsmarktperspectieven van de verschillende opleidingstypen waar meisjes of allochtonen zijn oververtegenwoordigd. 


\title{
3 Arbeidsmarktperspectieven voor meisjes
}

\author{
Meisjesopleidingen
}

Om de arbeidsmarktperspectieven van meisjes beter te kunnen beoordelen zal in dit hoofdstuk nader worden ingegaan op de perspectieven van wat men zou kunnen aanduiden als de "typische meisjesopleidingen". Deze opleidingen zijn bepaald aan de hand van de gegevens in de Enquête Beroepsbevolking (EBB). Er wordt van een "typische meisjesopleiding" gesproken als binnen de werkzame beroepsbevolking het aantal vrouwen meer dan twee derde van de groep werkenden met de desbetreffende opleidingsachtergrond uitmaakt. Tabel 3.1 geeft een overzicht van deze "meisjesopleidingen" en de bijbehorende arbeidsmarktperspectieven voor schoolverlaters. Het blijkt dat vooral de opleidingen in een paar verzorgende en dienstverlenende richtingen een relatief hoog aandeel meisjes kennen.

Tabel 3.1

Arbeidsmarktperspectieven voor "typische meisjesopleidingen" in 2002

\begin{tabular}{lll}
\hline Opleidingstype & ITA & Typering \\
\hline VBO verzorging & 1,02 & redelijk \\
MBO dokters-, tandarts- en dierenartsassistent & 1,11 & matig \\
MBO/LLW apothekersassistent & 0,97 & goed \\
MBO/LLW verpleging & 0,81 & zeer goed \\
MBO sociaal-cultureel & 1,01 & redelijk \\
MBO/LLW verzorging & 1,07 & matig \\
MBO/LLW uiterlijke verzorging & 0,88 & goed \\
MBO/LLW beweging en therapie & 1,07 & matig \\
MBO/LLW secretariaat & 0,89 & goed \\
MBO/LLW toerisme en recreatie & 1,29 & slecht \\
HBO lerarenopleiding basisonderwijs & 0,87 & goed \\
HBO lerarenopleiding medisch en verzorging & 0,87 & goed \\
HBO verpleegkunde & 0,87 & goed \\
HBO (fysio)therapie & 0,92 & goed \\
HBO voeding & 1,00 & reedelijk \\
HBO toerisme en recreatie & 1,03 & goed \\
HBO secretariaat & 0,88 & goed \\
HBO bibliotheek en documentatie & 0,91 & \\
\hline
\end{tabular}

Bron: ROA (1997c)

Op een paar uitzonderingen na zijn de arbeidsmarktperspectieven voor schoolverlaters uit de "meisjesopleidingen" goed. Zeer goede perspectieven zijn er zelfs voor het opleidingstype MBO/LLW verpleging. Uitzonderingen op het gunstige beeld zijn daarentegen het opleidingstype $M B O / L L W$ toerisme en recreatie met een slecht arbeidsmarktperspectief, en de opleidingen $M B O$ dokters-, tandarts en dierenartsassistenten, MBO/LLW verzorging en $M B O / L L W$ beweging en therapie met een matig perspectief.

Zoals in hoofdstuk 2 werd aangegeven, zijn de verwachte arbeidsmarktperspectieven van een bepaald opleidingstype gebaseerd op een vergelijking van aan de ene kant het verwachte aantal baanopeningen voor nieuwkomers op de arbeidsmarkt en 
aan de andere kant de arbeidsmarktinstroom van nieuwkomers en het aan het begin van de prognoseperiode 'boven de markt hangende' aanbod van kortdurig werklozen. Bij MBO/LLW verpleging is het totaal aantal verwachte baanopeningen in de periode 1997 tot 2002 ruim 47.000. Daartegen staat een arbeidsmarktinstroom van schoolverlaters van slechts 9.400. Daardoor zal de huidige werkloosheid van mensen met deze opleidingsachtergrond de komende jaren omslaan in een aanzienlijk aanbodtekort. Het slechte vooruitzicht voor de opleidingen MBO/LLW toerisme en recreatie en $M B O / L L W$ beweging en therapie is het gevolg van de te grote populariteit van deze opleidingen onder schoolverlaters. Beide opleidingstypen tonen weliswaar een stijgende werkgelegenheid, maar de vervangingsvraag is (erg) laag. Het aantal nieuwe baanopeningen dat daardoor beschikbaar komt is niet groot genoeg om de uitstroom van schoolverlaters op te vangen. Het verwachte aantal baanopeningen in de periode 1997-2002 is 5.000 voor MBO/LLW toerisme en recreatie en 8.000 voor $M B O / L L W$ beweging en therapie. De arbeidsmarktinstroom van schoolverlaters met deze opleidingsachtergronden is veel groter. Met andere woorden: beide opleidingstypen zijn gezien de omvang van de beschikbare werkgelegenheid te populair. Ditzelfde geldt (in mindere mate) voor het opleidingstype $M B O$ dokters-, tandarts en dierenartsassistenten. Hoewel de werkgelegenheid voor dit opleidingstype een stijgende tendens vertoont, is het aantal baanopeningen onvoldoende om alle schoolverlaters een goed arbeidsmarktperspectief te bieden. De opleiding $M B O / L L W$ verzorging vertoont een gelijkblijvende werkgelegenheid, en een lage vervangingsvraag, met als gevolg een laag aantal baanopeningen en een matig arbeidsmarktperspectief voor de schoolverlaters.

Voor het bepalen van de arbeidsmarktpositie van de schoolverlaters van een bepaalde opleiding is het ook belangrijk om de meer structurele kenmerken van de arbeidsmarktpositie te bekijken. Zo kan de keuze voor een bepaald opleidingstype een risico met zich meebrengen als men met de desbetreffende opleidingsachtergrond slechts in een beperkt aantal beroepen werk kan vinden, of als de beschikbaarheid van banen voor schoolverlaters met die achtergrond in hoge mate conjunctuurgevoelig is.

Tabel 3.2 geeft een overzicht van de uitwijkmogelijkheden op de arbeidsmarkt en de conjunctuurgevoeligheid van de werkgelegenheid waarmee schoolverlaters uit "typische meisjesopleidingen" geconfronteerd worden. Het blijkt dat de "typische meisjesopleidingen" gespecialiseerde opleidingen zijn: alleen met een opleiding VBO verzorging of $H B O$ secretariaat is men breder inzetbaar. Hoewel, zoals uit tabel 3.1 bleek, de huidige vooruitzichten voor de meeste "meisjesopleidingen" goed zijn, brengt deze geringe flexibiliteit op de arbeidsmarkt het risico met zich mee, dat men sterk afhankelijk is van de werkgelegenheidsontwikkeling in een vakspecifiek beroep en/of een bepaalde sector.

Daarentegen blijkt de conjunctuurgevoeligheid van de werkgelegenheid voor de schoolverlaters uit de "typische meisjesopleidingen" relatief laag te zijn. In tegenstelling tot jongens kiezen meisjes vaak voor opleidingen waarvan de werkgelegenheid niet of nauwelijks gevoelig is voor conjuncturele schommelingen. Enerzijds blijkt dus 
dat "meisjesopleidingen" gespecialiseerde opleidingen zijn, waarmee men maar in een beperkt aantal beroepen terecht kan, anderzijds blijkt de werkgelegenheid in die beroepen niet of nauwelijks aan conjuncturele schommelingen onderhevig te zijn. Dit gevoegd bij het feit dat de huidige verwachtingen voor schoolverlaters uit de "meisjesopleidingen" gunstig zijn, lijkt de conclusie gerechtvaardigd dat bij de meeste opleidingen meisjes vooral op de lange termijn duidelijke arbeidsmarktrisico's lopen. Uitzonderingen daarbij zijn vanzelfsprekend de in tabel 3.1 genoemde opleidingstypen met een matig of slecht perspectief. Bij de opleidingen MBO dokters- tandarts en dierenartsassistent en $M B O / L L W$ toerisme en recreatie gaat dit matige of slechte perspectief bovendien gepaard met geringe uitwijkmogelijkheden naar andere beroepsgroepen, hetgeen de arbeidsmarktrisico's van een dergelijke opleiding nog aanzienlijk vergroot.

Tabel 3.2

Uitwijkmogelijkheden en conjunctuurgevoeligheid voor "typische meisjesopleidingen", 19951996

\begin{tabular}{lll}
\hline Opleidingstype & Beroepenspreiding & $\begin{array}{l}\text { Conjunctuurgevoe- } \\
\text { ligheid }\end{array}$ \\
& & \\
\hline VBO verzorging & hoog & laag \\
MBO dokters-, tandarts- en dierenartsassistent & erg laag & laag \\
MBO/LLW apothekersassistent & erg laag & laag \\
MBO/LLW verpleging & erg laag & laag \\
MBO sociaal-cultureel & gemiddeld & gemiddeld \\
MBO/LLW verzorging & gemiddeld & gemiddeld \\
MBO/LLW uiterlijke verzorging & erg laag & gemiddeld \\
MBO/LLW beweging en therapie & gemiddeld & gemiddeld \\
MBO/LLW secretariaat & laag & gemiddeld \\
MBO/LLW toerisme en recreatie & laag & gemiddeld \\
HBO lerarenopleiding basisonderwijs & erg laag & gemiddeld \\
HBO lerarenopleiding medisch en verzorging & gemiddeld & gemiddeld \\
HBO verpleegkunde & erg laag & laag \\
HBO (fysio)therapie & erg laag & erg laag \\
HBO voeding & laag & erg laag \\
HBO toerisme en recreatie & gemiddeld & gemiddeld \\
HBO secretariaat & gemiddeld & gemiddeld \\
HBO bibliotheek en documentatie & erg laag & erg laag \\
\end{tabular}

\section{Bron: ROA (1997c)}

Er moet een opmerking geplaatst worden bij de bepaling van de "meisjes- en jongensopleidingen" op basis van de EBB. De EBB betreft de gehele werkzame bevolking, en niet alleen de schoolverlaters. Het gevolg hiervan is dat er sprake kan zijn van aanzienlijke cohorteffecten. Bedoeld wordt hiermee dat als in de loop van de tijd steeds meer meisjes voor een bepaalde opleiding kiezen, het mogelijk is dat een opleiding op basis van de EBB-cijfers nog een jongensopleiding genoemd wordt, terwijl de aantallen meisjes en jongens bij de huidige schoolverlaters meer in evenwicht zijn. Hierbij kan met name gedacht worden aan opleidingen op HBO- en WO-niveau. Op basis van de bij het ROA beschikbare uitstroomcijfers van school- 
verlaters kan tot op zekere hoogte een indruk van dit effect verkregen worden ${ }^{5}$. Voor een aantal opleidingstypen maakt het niet uit of de bepaling gebeurd op basis van de EBB of op basis van de schoolverlatersinformatie. In tabel 3.3 is een overzicht gegeven van de opleidingstypen, die op grond van de samenstelling van de huidige groep schoolverlaters van karakter zijn veranderd (hierbij blijven dan de WOopleidingen buiten beschouwing) ${ }^{6}$.

Tabel 3.3

Verschillen in indeling in jongens- en meisjes opleidingen op basis van de EBB en de schoolverlatersenquêtes

\begin{tabular}{ll}
\hline Opleidingstype & $\begin{array}{l}\text { Indeling op basis van } \\
\text { EBB }\end{array}$ \\
\hline
\end{tabular}

$\begin{array}{lcc}\text { VBO landbouw en natuurlijke omgeving } & j & n \\ \text { MBO/LLW landbouw en veeteelt } & j & n \\ \text { MBO/LLW grafische techniek } & j & n \\ \text { MBO/LLW procestechniek } & j & n \\ \text { MBO/LLW levensm. techniek/vleesverwerking } & j & n \\ \text { MBO/LLW horeca } & j & n \\ \text { MBO/LLW lerarenopleiding natuur en techniek } & j & n \\ \text { HBO milieukunde en levensm. technologie } & j & n \\ \text { HBO commerciële economie } & j & n \\ \text { HBO recht en bestuur } & j & n \\ \text { HBO bedrijfskunde } & j & m \\ \text { MBO/LLW brood en banket } & n & m \\ \text { HBO lerarenopleiding expressie } & n & m \\ \text { HBO tolk en vertaler } & n & m \\ \text { HBO maatsch.werk en dienstverlening } & n & m \\ \text { HBO personeelswerk } & n & \text { m }\end{array}$

j: jongensopleiding, m: meisjesopleiding, $\mathrm{n}$ : neutrale opleiding

Bron: ROA

Vergeleken met de indeling op basis van de EBB, blijkt het aantal "jongensopleidingen" kleiner te zijn: het aantal meisjes onder de schoolverlaters van een aantal van deze opleidingen is zo toegenomen dat ze inmiddels als "neutrale opleiding" ingedeeld moeten worden. Ook is er een aantal neutrale opleidingen waar het aandeel meisjes dusdanig gegroeid is dat ze inmiddels de classificatie van "meisjesopleiding" krijgen. Omdat er geen opleidingen verschoven zijn van de categorie "meisjesopleiding" naar de categorie "neutrale opleiding", of van "neutraal" naar "jongensopleiding", lijken de verschuivingen, afgezien van de verschillen in arbeidsmarktparticipatie, met name toegeschreven te kunnen worden aan een verandering in de opleidingskeuze van de meisjes. De emancipatie blijkt vooral een zaak van de

5. Hiervoor kan gebruik gemaakt worden van de schoolverlatersinformatie die beschikbaar is in de RUBS-enquête en de HBO-monitor (Zie ROA, 1997a). Deze schoolverlatersgegevens hebben, zoals reeds eerder is opgemerkt, alleen betrekking op het AVO, VBO, MBO en HBO onderwijs. Het universitaire onderwijs blijt derhalve buiten beschouwing.

6. Gezien de manier waarop deze indeling tot stand komt: een twee derde meerderheid van meisjes dan wel jongens binnen een opleidingstype of beroep, blijt er een derde groep opleidingen en beroepen over waarbinnen geen van beiden een meerderheid heeft. Deze groep zal aangeduid worden met de term "neutraal". 
meisjes geweest te zijn, het aantal jongens dat gekozen heeft voor een opleiding in een van oudsher "typische meisjesopleiding" is veel kleiner. Het gevolg hiervan is dat het aantal meisjesopleidingen groter geworden is ten opzicht van het aantal jongensopleidingen. Het zal echter nog wel enige tijd duren voordat deze verschuiving ook zichtbaar wordt in de samenstelling van de werkzame bevolking. Van deze 'nieuwe meisjesopleidingen' bieden de opleidingstypen HBO lerarenopleiding expressie, $H B O$ tolk en vertaler en $H B O$ maatschappelijk werk en dienstverlening naar verwachting een goed arbeidsmarktperspectief. Daarentegen is het opleidingstype $H B O$ personeelswerk het enige opleidingstype binnen het HBO waarvoor de perspectieven slecht zijn. Dit als gevolg van de te hoge arbeidsmarkt instroom van schoolverlaters.

\section{Meisjesberoepen}

De arbeidsmarktpositie van een schoolverlater wordt natuurlijk niet uitsluitend bepaald door de opleidingsachtergrond. Ook de beroepskeuze is van belang. Dit geldt met name voor de opleidingen met een hoge beroepenspreiding.

Vergelijkbaar met de manier waarop dat bij de opleidingen gedaan is, is er een overzicht gemaakt van "typische meisjesberoepen". Deze zijn hier gedefinieerd als de beroepsgroepen waarin tenminste twee derde van de werkenden vrouw is. In tabel 3.4 wordt een overzicht gegeven van deze beroepsgroepen, met daarbij telkens een indicatie van het aantal verwachte baanopeningen tot 2002 . Het blijkt dat de "typische meisjesberoepen" in het verlengde liggen van de "typische meisjesopleidingen": het zijn met name een aantal verzorgende en dienstverlenende beroepen waar de meerderheid van de werkenden vrouw is. Op basis van de in tabel 3.2 aangegeven geringe beroepenspreiding voor de "typische meisjesopleidingen" kon dit patroon in de meisjesberoepen al verwacht worden.

Uit de tabel blijkt dat er voor de meeste "meisjesberoepen" de komende jaren een gemiddeld tot relatief hoog aantal baanopeningen te verwachten is. Bovendien is de conjunctuurgevoeligheid van de werkgelegenheid in de meeste "meisjesberoepen" laag. Daarmee kan hetzelfde geconcludeerd worden als bij de "meisjesopleidingen". Weliswaar beslaan de opleidingen en beroepen waarbinnen meisjes in de meerderheid zijn relatief sterk afgebakende segmenten van de arbeidsmarkt, maar dit lijkt de komende jaren niet op grote risico's te duiden met betrekking tot de arbeidsmarktpositie van meisjes. Daarbij zijn er echter wel een aantal uitzonderingen aan te wijzen: voor de beroepen stewards en afdelingshoofden zorginstelling wordt tot 2002 weliswaar een groot aantal baanopeningen verwacht, maar de conjunctuurgevoeligheid van de werkgelegenheid in deze beroepsgroepen is hoog: mensen die werkzaam zijn in deze beroepen lopen op termijn een risico en schoolverlaters die zich specifiek richten op een functie als steward lopen het risico dat de arbeidsmarkt op het moment dat zij toetreden net in een laagconjunctuur zit, waardoor het aantal vacatures in deze beroepsgroep op dat moment laag is. Daarentegen zijn de risico's geringer bij beroepen met een hoog aantal baanopeningen en een lage conjunctuurgevoeligheid: dit betreft de vooruitzichten voor de verpleeghulpen en leerling-ver- 
pleegkundigen, apothekersassistenten en medisch laboranten, medisch secretaresses en de ziekenverzorgenden. Hierbij moet echter wel in ogenschouw worden genomen dat er bij de meeste van deze beroepen weinig uitwijkmogelijkheden zijn naar andere bedrijfssectoren, waardoor men sterk afhankelijk is van de werkgelegenheidsontwikkeling in de gezondheidszorg (zie ROA, 1997c).

Tabel 3.4

Baanopeningen (1997-2002) en conjunctuurgevoeligheid voor "typische meisjesberoepen"

\begin{tabular}{|c|c|c|}
\hline Beroepsgroep & Baanopeningen & $\begin{array}{l}\text { Conjunctuur- } \\
\text { gevoeligheid }\end{array}$ \\
\hline $\begin{array}{l}\text { Leraar basisonderwijs } \\
\text { Bibliothecarissen } \\
\text { Stewards } \\
\text { Verpleeghulpen en leerling-verpleegkundigen } \\
\text { Verplegenden en doktersassistenten } \\
\text { Therapeuten en verpleegkundigen } \\
\text { Apothekersassistenten en medisch laboranten } \\
\text { Medisch analisten } \\
\text { Afdelingshoofden zorginstelling } \\
\text { Receptionisten en administratieve employees } \\
\text { Medisch secretaresses } \\
\text { Interieurverzorgers } \\
\text { Verkopers } \\
\text { Hulpkrachten horeca en verzorging } \\
\text { Ziekenverzorgenden } \\
\text { Verzorgend personeel }\end{array}$ & $\begin{array}{l}\text { gemiddeld } \\
\text { gemiddeld } \\
\text { erg hoog } \\
\text { hoog } \\
\text { gemiddeld } \\
\text { gemiddeld } \\
\text { hoog } \\
\text { gemiddeld } \\
\text { gemiddeld } \\
\text { gemiddeld } \\
\text { hoog } \\
\text { gemiddeld } \\
\text { gemiddeld } \\
\text { gemiddeld } \\
\text { hoog } \\
\text { gemiddeld }\end{array}$ & $\begin{array}{l}\text { gemiddeld } \\
\text { erg laag } \\
\text { erg hoog } \\
\text { laag } \\
\text { laag } \\
\text { erg laag } \\
\text { laag } \\
\text { erg laag } \\
\text { hoog } \\
\text { laag } \\
\text { laag } \\
\text { erg laag } \\
\text { laag } \\
\text { gemiddeld } \\
\text { laag } \\
\text { gemiddeld }\end{array}$ \\
\hline
\end{tabular}

Bron: ROA (1997c)

\section{Jongensopleidingen}

Om een beeld te kunnen krijgen van de mogelijkheden om door de keuze voor een "typische jongensopleiding" een betere arbeidsmarktpositie te verkrijgen, wordt in tabel 3.5 een overzicht gegeven van de "jongensopleidingen" waarvoor de verwachte arbeidsmarktperspectieven voor de komende jaren zeer goed zijn ${ }^{7}$. Het criterium wanneer een opleiding een jongensopleiding is, is vergelijkbaar met de gehanteerde maatstaf bij het afbakenen van de "meisjesopleidingen". Als twee derde van de werkenden met de desbetreffende opleidingsachtergrond man is, wordt gesproken van "jongensopleiding". In de tabel wordt voor elk opleidingstype ook een indicatie gegeven van de uitwijkmogelijkheden op de arbeidsmarkt en de conjunctuurgevoeligheid van de werkgelegenheid. In vergelijking met de "typische meisjesopleidingen" vallen een paar zaken op. Tabel 3.5 laat zien dat er relatief veel technische opleidingen voorkomen waar de mannen in de meerderheid zijn. Wat ook opvalt in een vergelijking met de eerdere tabel voor de "meisjesopleidingen", is dat er relatief meer jongensopleidingen met een zeer goed perspectief zijn dan meisjesopleidingen. Met betrekking tot het niveau van de typische "jongens- en meisjes opleidingen"

7. In totaal worden er 113 opleidingstypen onderscheiden, waarvan 69 "jongensopleidingen" en 24 "meisjesopleidingen". Vanwege het grote aantal jongensopleidingen beperken we ons hier tot de opleidingstypen met een zeer goed arbeidsmarktperspectief. 
valt op dat er bij de "jongensopleidingen een relatief groot aantal opleidingen op HBO- of WO-niveau zijn, terwijl bij de meisjes de nadruk ligt op de MBO/LLWopleidingen. Dit verschil moet voor een deel toegeschreven worden aan het in tabel 3.3 geillustreerde cohort-effect dat optreedt als gevolg van de gebruikte data.

Tabel 3.5

Uitwijkmogelijkheden en conjunctuurgevoeligheid voor "typische jongensopleidingen" met zeer goede perspectieven, 1995-1996

\begin{tabular}{lll}
\hline Opleidingstype & Beroepenspreiding & $\begin{array}{l}\text { Conjunctuur- } \\
\text { gevoeligheid }\end{array}$ \\
& & \\
\hline MBO/LLW operationele techniek & laag & hoog \\
MBO/LLW procestechniek & laag & gemiddeld \\
MBO/LLW horeca & erg hoog & gemiddeld \\
HBO landbouw en veeteelt & gemiddeld & laag \\
HBO bouwkunde & laag & erg hoog \\
HBO informatica & erg laag & hoog \\
HBO vervoer en logistiek & gemiddeld & gemiddeld \\
HBO recht en bestuur & erg hoog & gemiddeld \\
WO bouwkunde & laag & gemiddeld \\
WO civiele techniek & gemiddeld & gemiddeld \\
WO informatica en best. informatiekunde & laag & hoog \\
WO tandheelkunde & erg laag & erg laag \\
WO bedrijfkunde & hoog & gemiddeld \\
WO accountancy en belastingen & laag & gemiddeld \\
\hline Bron: ROA (1997c) & & \\
\hline
\end{tabular}

Bron: ROA (1997c)

Ten aanzien van het structureel arbeidsmarktrisico kan opgemerkt worden dat er een duidelijk verschil bestaat tussen de diverse "meisjes-" en "jongensopleidingen": hoewel de arbeidsmarktperspectieven voor de "jongensopleidingen" de komende jaren zeer goed zijn, is de conjunctuurgevoeligheid van de werkgelegenheid bij deze opleidingstypen hoger dan bij de "typische meisjesopleidingen". Blijkbaar heeft de werkgelegenheid in de richtingen waar jongens in de meerderheid zijn een ander risicoprofiel dan de werkgelegenheid in de richtingen waar meisjes werkzaam zijn. De "meisjesopleidingen" worden gekenmerkt door een (erg) lage beroepenspreiding, gekoppeld aan een lage graad van conjunctuurgevoeligheid. De "jongensopleidingen" worden daarentegen vaker gekenmerkt door een hoge beroepenspreiding, gecombineerd met een hoge conjunctuurgevoeligheid van de werkgelegenheid.

\section{Beleidsimplicaties}

De vraag die op basis van de in dit hoofdstuk gepresenteerde informatie over de arbeidsmarktperspectieven gesteld kan worden, is waar er mogelijke verbeteringen liggen voor de arbeidsmarktperspectieven van meisjes. Er zijn dan in principe twee mogelijkheden, enerzijds kan er gestimuleerd worden dat meisjes binnen de categorie "typische meisjesopleidingen" en "typische meisjesberoepen" vaker kiezen voor opleidingstypen en de beroepsgroepen met de beste perspectieven. Anderzijds kan er getracht worden meisjes te stimuleren zich te richten op opleidingen en beroepen waar meisjes en jongens in min of meer gelijke mate voorkomen, of de opleidingen en beroepen die nu voornamelijk het domein zijn van jongens. 
Binnen de "typische meisjesopleidingen" zou dan gedacht kunnen worden aan het stimuleren van de studiekeuze in de richting van de opleidingen in de medisch/verzorgende richtingen op MBO-niveau en hoger. Als het er om gaat om opleidingen binnen de "typische jongensopleidingen" aan te geven waar mogelijk kansen liggen voor meisjes, zijn er uiteraard de technische opleidingen waarvoor de perspectieven goed tot erg goed zijn. Als nadelen voor die opleidingen geldt wel dat de huidige deelname van meisjes aan deze opleidingen laag is, dat de conjunctuurgevoeligheid van de werkgelegenheid relatief hoog is en dat bij sommige opleidingstypen de uitwijkmogelijkheden op de arbeidsmarkt relatief laag zijn. Al met al maakt dit het voor meisjes in het algemeen de komende jaren weinig aantrekkelijk om hun studiekeuze te verschuiven naar een technische opleiding. Het is moeilijk opleidingstypen aan te wijzen met goede arbeidsmarktperspectieven in combinatie met een laag structureel risico, waar meisjes geen pioniersrol hoeven te vervullen. Alleen de opleidingen $M B O / L L W$ horeca, $H B O$ recht en bestuur en WO bedrijfskunde voldoen aan alle drie deze criteria. Voor het overige worden in al deze beroepen meisjes geconfronteerd met ofwel een lage beroepenspreiding ofwel een hoge mate van conjunctuurgevoeligheid van de werkgelegenheid. Om een algeheel beeld te geven van de arbeidsmarktperspectieven en -risico's van de diverse opleidingstypen is als bijlage een tabel opgenomen met daarin alle onderscheiden opleidingstypen gerangschikt naar "meisjesopleidingen", "neutrale opleidingen" en "jongensopleidingen". Van deze opleidingen is telkens aangegeven het verwachte arbeidsmarktperspectief, de beroepenspreiding en de conjunctuurgevoeligheid van de werkgelegenheid.

Overigens moet bedacht worden dat het verkleinen van de verschillen van de arbeidsmarktperspectieven tussen jongens en meisjes ook bewerkstelligd zou kunnen worden door jongens te stimuleren vaker te kiezen voor een "meisjesopleiding of -beroep". Tot nu toe blijkt de emancipatie voornamelijk een zaak van de meisjes te zijn geweest: de aantallen jongens in de meisjesopleidingen zijn klein gebleven. Toch zijn er onder de "meisjesopleidingen" opleidingen met een goed perspectief, die ook voor jongens een perspectiefrijk alternatief kunnen zijn, bijvoorbeeld de HBO-opleidingen verpleegkunde en (fysio)therapie.

Er moet op deze plaats nog een kanttekening gemaakt worden bij het stimuleren van de studiekeuze voor bepaalde opleidingen. $\mathrm{Er}$ is een aantal opleidingstypen dat voor de komende jaren een goed perspectief heeft, maar qua aantal werkenden slechts betrekking heeft op een klein arbeidsmarktsegment. Derhalve is het niet zinvol om de keuze voor deze richting te sterk te stimuleren. Vanwege het kleine aantal baanopeningen, zal het verwachte perspectief immers heel snel verslechteren als het aantal schoolverlaters met deze opleidingsachtergrond sterk toeneemt. Dit geldt met name voor de opleidingen $M B O / L L W$ operationele techniek, waarvoor in de periode 1997-2002 slechts 3.200 baanopeningen verwacht worden, HBO landbouw en veeteelt met 4.800 baanopeningen en de WO-opleidingen bouwkunde, civiele techniek en tandheelkunde. De verwachte baanopeningen voor deze drie opleidingstypen zijn respectievelijk $4.900,3.400$ en 2.100 . Omdat deze opleidingen ook een 
relatief lage beroepenspreiding kennen lopen mensen met een dergelijke opleidingsachtergrond bij een aanbodoverschot een groot risico. 


\section{Ontwikkelingen in deeltijdwerk}

In de discussie die er gaande is over de combinatie van werk en zorgtaken keert regelmatig de vraag terug in welke mate het mogelijk is om een baan in deeltijd te vervullen. Dit zou slechts mogelijk zijn in een beperkt aantal beroepen. Doorgaans wordt dan gesteld dat het voor vrouwen wel, en voor mannen in de praktijk niet goed mogelijk is om in deeltijd te werken. In dit hoofdstuk wordt een overzicht gegeven van de mate waarin in deeltijd wordt gewerkt per opleidingstype en per beroepsgroep $^{8}$. Hierbij is dan, net zoals in het vorige hoofdstuk, onderscheid gemaakt naar "typische meisjes- en jongensopleidingen" en naar "typische meisjes- en jongensberoepen".

\section{Opleidingstypen}

De tabel 4.1 geeft een beeld van de mate waarin deeltijdwerk voorkomt binnen achtereenvolgens de "typische meisjesopleidingen", "neutrale opleidingen" en de "jongensopleidingen". Uit de tabel blijkt dat er voor de "typische meisjesopleidingen" sprake is van een zeer hoge mate van deeltijdwerk, en dat deeltijdarbeid nog steeds toeneemt.

Tabel 4.1

Mate van deeltijdwerk gerangschikt naar "meisjes-", "neutrale" en "jongensopleidingen"

\begin{tabular}{lll}
\hline Opleidingstype & $\%$ & Trend \\
\hline & & \\
MEISJES & & \\
VBO verzorging & & constant \\
MBO dokters-, tandarts- en dierenartsassistent & 67 & stijgend \\
MBO/LLW apothekersassistent & 59 & stijgend \\
MBO/LLW verpleging & 59 & stijgend \\
MBO sociaal-cultureel & 64 & constant \\
MBO/LLW verzorging & 47 & stijgend \\
MBO/LLW uiterlijke verzorging & 67 & stijgend \\
MBO/LLW beweging en therapie & 54 & stijgend \\
MBO/LLW secretariaat & 55 & stijgend \\
MBO/LLW toerisme en recreatie & 51 & stijgend \\
HBO lerarenopleiding basisonderwijs & 29 & stijgend \\
HBO lerarenopleiding medisch en verzorging & 39 & constant \\
HBO verpleegkunde & 62 & stijgend \\
HBO (fysio)therapie & 45 & constant \\
HBO voeding & 54 & - \\
HBO toerisme en recreatie & 53 & sterk stijgend \\
HBO secretariaat & 31 & constant \\
HBO bibliotheek en documentatie & 33 & -
\end{tabular}

8. Deeltijdarbeid betreft hier personen die hoogstens 32 uur maar minstens 12 uur per week werkzaam zijn. 
Tabel 4.1 (vervolg)

Mate van deeltijdwerk gerangschikt naar "meisjes-", "neutrale" en "jongensopleidingen"

\begin{tabular}{llll}
\hline Opleidingstype & $\%$ & Trend
\end{tabular}

NEUTRAAL

MAVO

VBO administratie, handel en textiel

HAVONWO

MBO/LLW laboratorium

MBO/LLW administratie

MBO/LLW handel

HBO lerarenopleiding talen

HBO lerarenopleiding economie en maatschappi

$\mathrm{HBO}$ lerarenopleiding expressie

$\mathrm{HBO}$ tolk en vertaler

HBO laboratorium

HBO communicatie en journalistiek

HBO maatschappelijk werk en hulpverlening

HBO personeelswerk

$\mathrm{HBO}$ uitvoerende en beeldende kunsten

WO letteren

WO farmacie

WO rechten en bestuurskunde

WO sociale wetenschappen

WO kunstwetenschappen

Trend

\section{JONGENS}

Basisonderwijs

VBO landbouw en natuurlijke omgeving

VBO bouwtechniek

VBO installatietechniek

VBO mechanische techniek

VBO fijnmechanische techniek

VBO motorvoertuigentechniek

VBO elektrotechniek

VBO grafische techniek

VBO brood en banket

VBO horeca en levensmiddelentechniek

VBO vervoer

VBO beveiliging

MBO/LLW landbouw en veeteelt

$\mathrm{MBO} / \mathrm{LLW}$ milieu en groene ruimte

MBO/LLW bouw

MBO/LLW grond-, weg- en waterbouw

MBO/LLW installatietechniek

MBO/LLW werktuigbouw en mechanische techniek

MBO/LLW fijnmechanische techniek

$\mathrm{MBO} / \mathrm{LLW}$ motorvoertuigentechniek

MBO/LLW vliegtuigtechniek

MBO/LLW operationele techniek

MBO/LLW elektrotechniek

$\mathrm{MBO} / \mathrm{LLW}$ grafische techniek

MBO/LLW procestechniek

$\mathrm{MBO} / \mathrm{LL} W$ brood en banket

MBO/LLW levensmiddelentechniek/vleesverwerking

MBO/LLW vervoer

MBO/LLW gezondheidstechniek

MBO/LLW horeca

$\mathrm{MBO} / \mathrm{LLW}$ bedrijfskunde

MBO/LLW automatisering

MBO/LLW geld, bank en belastingen

MBO verzekeringswezen

MBO openbare orde en veiligheid

$\begin{array}{ll}36 & \text { stijgend } \\ 41 & \text { constant } \\ 33 & \text { stijgend } \\ 29 & \text { sterk stijgend } \\ 20 & \text { stijgend } \\ 23 & \text { stijgend } \\ 41 & \text { constant } \\ 29 & \text { stijgend } \\ 47 & \text { constant } \\ 54 & \text { sterk stijgend } \\ 30 & \text { stijgend } \\ 26 & \text { sterk stijgend } \\ 50 & \text { stijgend } \\ 19 & - \\ 38 & \text { stijgend } \\ 37 & \text { stijgend } \\ - & \text { constant } \\ 18 & \text { stijgend } \\ 37 & \text { constant } \\ - & -\end{array}$

$\begin{array}{ll}28 & \text { stijgend } \\ 13 & \text { stijgend } \\ 8 & \text { stijgend } \\ \text { sterk stijgend } \\ - & \text { stijgend } \\ 6 & - \\ - & \text { sterk dalend } \\ 7 & \text { stijgend } \\ 9 & - \\ - & \text { stijgend } \\ - & \text { stijgend } \\ 26 & - \\ - & \text { sterk stijgend } \\ - & \text { stijgend } \\ 10 & - \\ - & \text { sterk stijgend } \\ 6 & - \\ - & \text { sterk dalend } \\ - & \text { sterk stijgend } \\ 4 & \text { stijgend } \\ - & - \\ 5 & \text { constant } \\ - & - \\ - & - \\ 3 & - \\ 8 & \text { constant } \\ - & - \\ - & \text { sterk stijgend } \\ - & \text { constant } \\ 11 & - \\ - & \text { stijgend } \\ 18 & \text { sterk stijgend } \\ 10 & \text { stijgend } \\ 14 & \text { sterk stijgend } \\ 17 & \text { stijgend } \\ 15 & \text { sterk stijgend } \\ 7 & \\ & \end{array}$


Tabel 4.1 (vervolg)

Mate van deeltijdwerk gerangschikt naar "meisjes-", "neutrale" en "jongensopleidingen"

\begin{tabular}{|c|c|c|}
\hline Opleidingstype & $\%$ & Trend \\
\hline $\begin{array}{l}\text { HBO lerarenopleiding natuur en techniek } \\
\text { HBO lerarenopleiding lichamelijke opvoeding } \\
\text { HBO landbouw en veeteelt } \\
\text { HBO milieukunde en levensmiddelentechnologie } \\
\text { HBO bouwkunde } \\
\text { HBO civiele techniek } \\
\text { HBO werktuigbouwkunde } \\
\text { HBO elektrotechniek } \\
\text { HBO informatica } \\
\text { HBO chemische technologie } \\
\text { HBO vervoer en logistiek } \\
\text { HBO accountancy en bedrijfseconomie } \\
\text { HBO commerciële economie } \\
\text { HBO recht en bestuur } \\
\text { HBO bedrijfskunde } \\
\text { HBO openbare orde en veiligheid } \\
\text { WO theologie } \\
\text { WO landbouw en milieukunde } \\
\text { WO wiskunde en natuurwetenschappen } \\
\text { WO bouwkunde } \\
\text { WO civiele techniek } \\
\text { WO werktuigbouwkunde } \\
\text { WO elektrotechniek } \\
\text { WO informatica en bestuurlijke informatiekunde } \\
\text { WO (dier)geneeskunde } \\
\text { WO tandheelkunde } \\
\text { WO econom(etr)ie } \\
\text { WO bedrijfskunde } \\
\text { WO accountancy en belastingen }\end{array}$ & $\begin{array}{l}17 \\
28 \\
- \\
- \\
- \\
- \\
- \\
- \\
11 \\
- \\
- \\
10 \\
7 \\
22 \\
11 \\
- \\
- \\
23 \\
15 \\
- \\
- \\
- \\
- \\
- \\
18 \\
- \\
10 \\
- \\
-\end{array}$ & $\begin{array}{l}\text { constant } \\
\text { constant } \\
- \\
\text { sterk stijgend } \\
\text { sterk stijgend } \\
\text { constant } \\
\text { stijgend } \\
\text { sterk stijgend } \\
\text { sterk stijgend } \\
\text { sterk stijgend } \\
\text { sterk stijgend } \\
\text { sterk stijgend } \\
\text { - } \\
\text { sterk stijgend } \\
\text { sterk stijgend } \\
\text { sterk stijgend } \\
\text { - } \\
\text { stijgend } \\
\text { stijgend } \\
\text { sterk stijgend } \\
\text { sterk stijgend } \\
\text { - } \\
\text { stijgend } \\
\text { - } \\
\text { constant } \\
\text { constant } \\
\text { constant } \\
\text { sterk stijgend } \\
\text { - }\end{array}$ \\
\hline
\end{tabular}

Bron: ROA (1997c)

Uit de tabel blijkt dat dit eveneens het geval is bij de "neutrale opleidingen", hoewel de mate waarin deeltijdwerk bij degenen met deze opleidingsachtergrond voorkomt al lager ligt dan voor de meisjesopleidingen. Het blijkt echter dat er door diegenen die een "typische jongensopleiding" gevolgd hebben momenteel veel minder in deeltijd wordt gewerkt. De mate waarin in deeltijd wordt gewerkt loopt in de meisjesopleidingen uiteen van $29 \%$ (MBO/LLW toerisme en recreatie) tot $67 \%$ (zowel VBO als $M B O / L L W$ verzorging). Voor de neutrale opleidingen loopt het werkgelegenheidsaandeel van de deeltijders uiteen van $18 \%$ (WO rechten en bestuurskunde) tot $54 \%$ (HBO tolk en vertaler). Voor de jongensopleidingen tenslotte loopt het percentage deeltijders uiteen van $3 \%$ (MBO/LLW elektrotechniek) tot $28 \%$ (HBO lerarenopleiding lichamelijke opvoeding). Naast dit laatste opleidingstype zijn er bij de jongensopleidingen slechts een paar opleidingstypen waar reeds een relatief hoge mate van deeltijdwerk voorkomt en waar de mate waarin in deeltijd wordt gewerkt een stijgende trend vertoont, te weten MBO/LLW horeca $(18 \%), M B O / L L W$ geld, bank en belastingen (17\%), HBO recht en bestuur (22\%) en WO landbouw en milieukunde (23\%). 


\section{Beroepsgroepen}

Bovenstaande cijfers geven aan dat er een duidelijk verschil bestaat tussen jongensen meisjesopleidingen voor wat betreft de mate waarin in deeltijd gewerkt wordt. Op basis van deze gegevens is het niet mogelijk om een uitspraak te doen over de vraag wat de oorzaak is van het lage percentage mannen dat in deeltijd werkt. Op het eerste gezicht lijkt het alsof mensen die voorkeur hebben voor een deeltijdbaan, er beter aandoen zich te richten op een typisch meisjesberoep, terwijl mensen met een voorkeur voor een voltijdsbaan een grotere kans hebben binnen de jongensopleidingen. De vraag is echter of mannen weinig in deeltijdwerk werken omdat er de mogelijkheden niet voor zijn, of omdat ze nog altijd de voorkeur geven aan voltijdswerk. Als dat laatste het geval is, dan is de bovenstaande conclusie misschien iets te voorbarig. Wel blijkt dat bij een groot aantal opleidingstypen, waaronder ook een groot aantal "typische jongensopleidingen", het aandeel van deeltijdwerk een stijgende trend vertoont. Dit betekent dat de mogelijkheden om in deeltijd te werken voor mannen in ieder geval steeds groter worden.

In tabel 4.2 staat een overzicht gegeven van de mate waarin deeltijdwerk voorkomt binnen de onderscheiden beroepsgroepen. Ook hier blijkt weer dat het percentage deeltijdwerkers groter is naarmate er meer vrouwen in een beroep werkzaam zijn. De mate waarin deeltijdwerk voorkomt binnen de vrouwenberoepen loopt uiteen van $35 \%$ bij de beroepsgroep Leraar basisondenwijs tot $72 \%$ bij de Hulpkrachten horeca en verzorging. Voor de neutrale beroepen loopt dit percentage uiteen van $14 \%$ bij de beroepsgroep Assistent accountants tot $65 \%$ bij de Ondersteunende administratieve hulpkrachten. Bij de mannenberoepen ligt het werkgelegenheidsaandeel van de deeltijdwerkers beduidend lager: van $4 \%$ bij de Monteurs tot $43 \%$ bij de Sportinstructeurs. Ook hier is het niet duidelijk of de grote verschillen tussen "meisjes-" en "jongensberoepen" in de mate waarin in deeltijd wordt gewerkt, veroorzaakt wordt door verschillen tussen de mogelijkheden om in deze beroepen in deeltijd te werken, of door verschillen tussen jongens en meisjes in de voorkeuren om in deeltijd te werken. Met ander woorden: willen mannen niet in deeltijd werken of krijgen ze er de mogelijkheden niet toe in de beroepen waarin ze werkzaam zijn? Wel blijkt eveneens uit deze tabellen dat er ook bij de "typische jongensberoepen" beroepsgroepen voorkomen waarbinnen deeltijdwerk een steeds meer voorkomend verschijnsel is. De mogelijkheden om in deeltijd te werken zijn relatief groot en worden ook steeds groter bij bijvoorbeeld docenten en journalisten. Aan de andere kant zijn er beroepen waarbinnen het percentage deeltijdwerkers laag is, en dat gezien de trend voorlopig ook zal blijven: bouwvakkers, metaalarbeiders en monteurs.

Gezien de algemene trend van stijgende aantallen deeltijdwerkers is het opvallend dat er beroepsgroepen zijn waarvoor de mate waarin in deeltijd wordt gewerkt een dalende tendens vertoont: bijvoorbeeld Docenten exacte, medische en verzorgende vakken (2e graads), Onderwijskundige medewerkers, confectie-arbeiders, en schoen- en kleermakers. Een mogelijke verklaring voor deze stijgende tendens zou kunnen zijn dat door de verbeterde arbeidsmarktsituatie meer mensen die dit ambiëren een voltijdse aanstelling kunnen krijgen. Gezien de verwachte goede 
arbeidsmarktperspectieven voor veel opleidingstypen zou dit de komende jaren bij meer opleidingen een rol kunnen gaan spelen.

Tabel 4.2

De mate van deeltijdwerk gerangschikt naar "meisjes-", "neutrale" en "jongensberoepen"

\begin{tabular}{|c|c|c|}
\hline Beroep & $\%$ & Trend \\
\hline \multicolumn{3}{|l|}{ MEISJES } \\
\hline Leraar basisonderwijs & 35 & stijgend \\
\hline Bibliothecarissen & 53 & - \\
\hline Stewards & 36 & constant \\
\hline Verpleeghulpen en leerling-verpleegkundigen & 38 & sterk stijgend \\
\hline Verplegenden en doktersassistenten & 59 & stijgend \\
\hline Therapeuten en verpleegkundigen & 55 & stijgend \\
\hline Apothekersassistenten en medisch laboranten & 44 & stijgend \\
\hline Medisch analisten & 43 & constant \\
\hline Afdelingshoofden zorginstelling & 45 & - \\
\hline Receptionisten en administratieve employees & 47 & constant \\
\hline Medisch secretaresses & 63 & stijgend \\
\hline Interieurverzorgers & 70 & constant \\
\hline Verkopers & 57 & stijgend \\
\hline Hulpkrachten horeca en verzorging & 72 & constant \\
\hline Ziekenverzorgenden & 68 & constant \\
\hline Verzorgend personeel & 59 & stijgend \\
\hline \multicolumn{3}{|l|}{ NEUTRAAL } \\
\hline Docenten exacte, medische en verzorgende vakken ( $2 \mathrm{e}$ graads) & 39 & dalend \\
\hline Docenten economisch-administratieve vakken (2e graads) & 30 & constant \\
\hline Docenten talen en expressie & 55 & constant \\
\hline Docenten letteren (1e graads) & 45 & stijgend \\
\hline Docenten sociale vakken (1e graads) & 44 & stijgend \\
\hline Docenten 2 e graads zonder specialisatie & 31 & - \\
\hline Onderwijskundig medewerkers & 34 & dalend \\
\hline Onderwijskundigen en pedagogen & 42 & - \\
\hline Zweminstructeurs & 56 & sterk stijgend \\
\hline Tolken, vertalers en schrijvers & 41 & constant \\
\hline Bibliotheekassistenten & 41 & constant \\
\hline Kunstenaars & 33 & - \\
\hline Taalkundigen & 27 & stijgend \\
\hline Agrarische hulparbeiders & 58 & sterk stijgend \\
\hline Laboratorium-assistenten & - & $-\ldots$ \\
\hline Laboranten & 18 & stijgend \\
\hline Confectie-arbeiders & 28 & dalend \\
\hline Apothekers & - & - \\
\hline Kantoorhulpen, inpakkers en colporteurs & 33 & stijgend \\
\hline Ondersteunende administratieve hulpkrachten & 65 & constant \\
\hline Boekhouders en secretaresses & 34 & stijgend \\
\hline Assistent accountants & 14 & stijgend \\
\hline Verzekeringsagenten & 29 & stijgend \\
\hline Commercieel employees & 19 & stijgend \\
\hline Juristen & 18 & stijgend \\
\hline Activiteitenbegeleiders en medewerkers arbeidsbemiddeling & 46 & stijgend \\
\hline Sociaal-cultureel werkers & 40 & constant \\
\hline Sociale raadslieden en hoofden personeelszaken & 46 & constant \\
\hline Sociaal-wetenschappelijk medewerkers & - & - \\
\hline Sociaal-wetenschappelijk onderzoekers & 40 & stijgend \\
\hline Vakkenvullers & 65 & - \\
\hline Winkeliers & 14 & stijgend \\
\hline
\end{tabular}


Tabel 4.2 (vervolg)

De mate van deeltijdwerk gerangschikt naar "meisjes-", "neutrale" en "jongensberoepen"

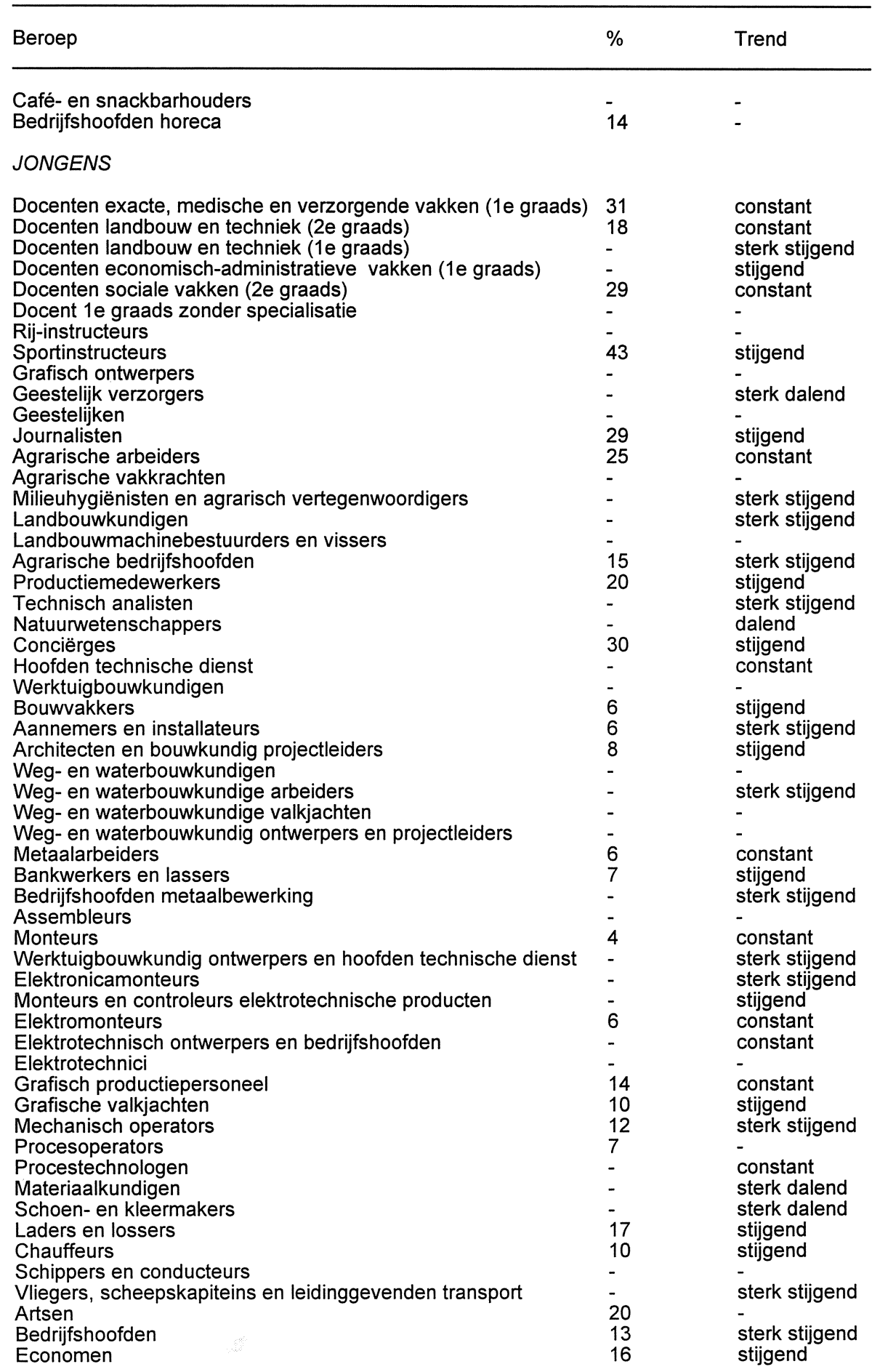


Tabel 4.2 (vervolg)

De mate van deeltijdwerk gerangschikt naar "meisjes-", "neutrale" en "jongensberoepen"

\begin{tabular}{lll}
\hline Beroep & $\%$ & Trend \\
\hline & & \\
Productieplanners & 12 & stijgend \\
Organisatieadviseur & 15 & sterk stijgend \\
Organisatiedeskundigen & 15 & constant \\
Accountants & - & constant \\
Commercieel medewerkers & 9 & sterk stijgend \\
Technisch-commercieel employés & - & sterk stijgend \\
Technisch-bedrijfsundig medewerkers & - & stijgend \\
Juridisch en fiscaal medewerkers & 17 & - \\
Juridisch, bestuurlijk medewerkers & - & sterk dalend \\
Administratieve transportemployés & - & - \\
Leidinggevenden & 5 & sterk stijgend \\
Managers & 9 & constant \\
Programmeurs & 8 & - \\
Systeemanalisten & 9 & - \\
Informatici & - & sterk stijgend \\
Technisch systeemanalisten & - & sterk stijgend \\
Bakkers en slagers & - & sterk stijgend \\
Aspirant politieagenten, soldaten en beveiligingshulpkrachten & sterk stijgend \\
Politieagenten, onderofficieren en beveiligingemployés & -13 & - \\
Politie-inspecteurs en officieren & 6 & - \\
Brandweerlieden & - & \\
& - & \\
\hline Bron ROA (1997c) & & \\
\hline
\end{tabular}

Bron ROA (1997c) 


\section{Arbeidsmarktperspectieven voor allochtonen}

Op eenzelfde wijze als in hoofdstuk 3 een overzicht gegeven is van de verwachte arbeidsmarktperspectieven van meisjes gerelateerd aan de perspectieven van een aantal "typische meisjesopleidingen", zal in dit hoofdstuk een overzicht gegeven worden van de arbeidsmarktperspectieven voor allochtone schoolverlaters. Het overzicht zal dus gegeven worden aan de hand van de perspectieven van schoolverlaters van opleidingstypen die vaak door allochtonen worden gevolgd. Voor de in dit rapport gegeven overzichten is uitgegaan van de zogenaamde WBEAA-definitie van allochtonen ${ }^{9}$. Dit houdt in dat niet alle schoolverlaters van niet-Nederlandse afkomst opgenomen zijn, maar slechts zij die onder de WBEAA-definitie vallen ${ }^{10}$.

Tabel 5.1

Arbeidsmarktperspectieven voor de opleidingstypen met een relatief groot aandeel allochtone schoolverlaters

\begin{tabular}{llll}
\hline Opleidingstype & ITA & Typering & $\begin{array}{c}\text { \% Allochtone } \\
\text { schoolverlaters }\end{array}$ \\
\hline VBO installatietechniek & & slecht & 25 \\
VBO administratie, handel en textiel & 1,23 & slecht & 20 \\
VBO motorvoertuigentechniek & 1,17 & redelijk & 19 \\
VBO mechanische techniek & 0,98 & goed & 16 \\
VBO bouwtechniek & 1,03 & redelijk & 10 \\
MBO/LLW beweging en therapie & 1,07 & matig & 10 \\
MBO/LLW installatietechniek & 0,92 & goed & 8 \\
VBO verzorging & 1,02 & redelijk & 7 \\
HBO lerarenopleiding talen & 0,88 & goed & 7 \\
HBO recht en bestuur & 0,69 & zeer goed & 6
\end{tabular}

a) Als percentage van het totaal aantal schoolverlaters van het desbetreffende opleidingstype Bron: ROA (1997c), RUBS, 1996

Om een inzicht te krijgen in de opleidingstypen die voor allochtonen jongeren van belang zijn, is op basis van de schoolverlatersinformatie nagegaan welke opleidingen een relatief hoog percentage allochtone schoolverlaters kennen. In tabel 5.1 staat de 'top-10' van opleidingstypen met een relatief hoog percentage allochtone schoolverlaters. Bij deze opleidingen spant VBO installatietechniek de kroon: $25 \%$ van de schoolverlaters is van allochtone afkomst. De arbeidsmarktperspectieven voor deze VBO-opleiding zijn slecht. Hetzelfde geldt voor de opleiding VBO administratie, handel en techniek, waar bijna $20 \%$ van de schoolverlaters van allochtone afkomst is. Bij de VBO-opleidingen die een beter arbeidsmarktperspectief hebben, moet overigens wel een relativerende opmerking gemaakt worden. De oorzaak voor

9. WBEAA: Wet Bevordering Evenredige Arbeidsdeelname Allochtonen.

10. De WBEAA landen zijn: Aruba, Nederlandse Antillen, Ethiopië, Irak, Iran, voormalig Joegoslavië, Marokko, Somalië, Suriname, Turkije en Vietnam. Op grond van deze wet worden niet alleen diegenen die uit de genoemde landen afkomstig zijn tot de allochtonen gerekend, maar ook de kinderen van deze allochtonen, ongeacht of zij de Nederlandse nationaliteit bezitten. 
dit gunstige arbeidsmarktperspectief ligt geheel aan de aanbodkant. Steeds minder schoolverlaters betreden de arbeidsmarkt met uitsluitend een VBO-diploma, terwijl bovendien veel van hen na enkele jaren alsnog een diploma op MBO/LLW-niveau behalen. Op langere termijn is de positie op de arbeidsmarkt voor de schoolverlaters met uitsluitend een VBO-diploma die geen aanvullende opleiding volgen, echter niet rooskleurig: de beschikbare baanopeningen voor lager opgeleiden zijn vooral het gevolg van de hoge arbeidsmarktuitstroom van laaggeschoolden op relatief jonge leeftijd. Deze uitstroom creëert weliswaar een vervangingsvraag voor schoolverlaters met een lagere opleiding, maar als de arbeidsmarkt in dit opzicht niet verandert, hebben ook zij slechts een perspectief op een betrekkelijk kortstondig verblijf op de arbeidsmarkt.

In tabel 5.2 is een overzicht gegeven van de uitwijkmogelijkheden op de arbeidsmarkt en de conjunctuurgevoeligheid van de werkgelegenheid voor de opleidingen waarvan een relatief groot deel van de schoolverlaters van allochtone afkomst is. Voor de VBO-opleidingen in de technische richting geldt dat de uitwijkmogelijkheden op de arbeidsmarkt naar verschillende beroepsgroepen relatief groot zijn, maar ook dat de conjuncturele risico's heel hoog zijn. Dit gekoppeld aan de reeds genoemde slechte vooruitzichten voor schoolverlaters met een VBO-achtergrond, lijkt het dat de arbeidsmarktpositie van allochtonen vooral verbeterd kan worden door allochtone jongeren te stimuleren om opleidingen op MBO/leerlingwezen-niveau en hoger te gaan volgen.

Tabel 5.2

Uitwijkmogelijkheden en conjunctuurgevoeligheid van opleidingen met een relatief groot aandeel allochtonen

\begin{tabular}{lll}
\hline Opleidingstype & Beroepenspreiding & $\begin{array}{l}\text { Conjunctuur- } \\
\text { gevoeligheid }\end{array}$ \\
\hline VBO installatietechniek & & erg hoog \\
VBO administratie, handel en textiel & gemiddeld & hoog \\
VBO motorvoertuigentechniek & gemiddeld & hoog \\
VBO mechanische techniek & hoog & hoog \\
VBO bouwtechniek & laag & erg hoog \\
MBO/LLW beweging en therapie & gemiddeld & gemiddeld \\
MBO/LLW installatietechniek & erg laag & erg hoog \\
VBO verzorging & hoog & laag \\
HBO lerarenopleiding talen & laag & gemiddeld \\
HBO recht en bestuur & erg hoog & gemiddeld \\
\hline
\end{tabular}

Bron: ROA (1997c)

Een nadeel van op deze manier een overzicht te geven van schooltypen met relatief veel allochtonen, is dat geen beeld wordt gegeven van de voor allochtonen belangrijkste opleidingen. Immers, sommige van de in tabel 5.2 genoemde opleidingstypen zijn vrij klein, waardoor het aantal allochtone schoolverlaters in absolute zin erg klein is. Dit geldt met name voor de beide genoemde HBO-opleidingen. Om dit bezwaar te ondervangen is ook op een tweede manier bepaald welke opleidingstypen voor allochtone jongeren van belang zijn. 
Tabel 5.3

Arbeidsmarktperspectieven voor de meest voorkomende opleidingen onder allochtone jongeren, onderverdeeld naar geslacht

\begin{tabular}{|c|c|c|c|}
\hline Opleidingstype & ITA & Typering & $\begin{array}{l}\text { \% Allochtone } \\
\text { schoolverlaters }\end{array}$ \\
\hline
\end{tabular}

\section{TOTAAL}

VBO administratie, handel en textiel HAVO/NWO

1,17

1,05

MBO/LLW administratie

VBO mechanische techniek

VBO verzorging

MAVO

VBO motorvoertuigentechniek

VBO bouwtechniek

MBO/LLW handel

$\mathrm{MBO} / \mathrm{LLW}$ beweging en therapie

\section{JONGENS}

VBO administratie, handel en textiel VBO mechanische techniek

VBO motorvoertuigentechniek

VBO bouwtechniek

MBO/LLW administratie

HAVONWO

MBO/LLW elektrotechniek

MAVO

MBO/LLW beweging en therapie

$\mathrm{MBO} / \mathrm{LLW}$ handel

0,9

0,98

1,02

0,97

1,05

1,03

1,02

1,07

slecht
redelijk
goed
goed
redelijk
goed
redelijk
redelijk
redelijk
matig

20

10

6

6

6

MEISJES

VBO administratie, handel en textiel HAVO/WWO

VBO verzorging

MBO/LLW administratie

MAVO

MBO/LLW handel

$\mathrm{MBO} / \mathrm{LLW}$ beweging en therapie

MBO sociaal-cultureel

MBO/LLW verpleging

MBO/LLW verzorging

1,17
0,98
1,05
1,03
0,96
1,05
0,93
0,97
1,07
1,02

slecht
goed
redelijk
redelijk
goed
redelijk
goed
goed
matig
redelijk

18

10

10

7

5

5

4
4

a) Als percentage van de totale groep allochtone schoolverlaters (resp. voor jongens en meisjes)

Bron: ROA (1997c)

Tabel 5.3 geeft een overzicht van opleidingen die voor allochtonen van belang zijn, niet geordend naar het percentage schoolverlaters dat van allochtone afkomst is, maar naar de verdeling van de allochtonen over de diverse opleidingstypen. Hierbij moet worden opgemerkt dat deze cijfers gebaseerd zijn op de eerder genoemde schoolverlatersenquêtes die alleen betrekking hebben op het $A V O, V B O, M B O$ en HBO. Een direct gevolg hiervan is dat schoolverlaters met alleen basisschool en de afgestudeerden van het universitair onderwijs buiten beschouwing blijven. De genoemde opleidingstypen beslaan ongeveer driekwart van de totale groep allochtone schoolverlaters op de desbetreffende opleidingsniveaus. De totale spreiding van 
de allochtonen over de verschillende opleidingstypen is dus veel groter dan deze tabel suggereert.

De verdeling van allochtone jongens en meisjes over de opleidingstypen wijkt sterk af van die van de jongens en meisjes in het algemeen. Zo heeft $56 \%$ van de allochtone jongens een diploma op VBO-niveau terwijl dit voor de jongens in het algemeen slechts $19 \%$ is. Voor meisjes zijn deze cijfers $36 \%$ en $13 \%$ respectievelijk. De participatie van allochtonen op HBO-niveau is veel lager: ongeveer $6 \%$ van de allochtone schoolverlaters heeft een diploma op HBO-niveau, terwijl dit percentage voor de schoolverlaters in het algemeen net boven de $13 \%$ ligt.

Ook uit tabel 5.3 blijkt dat veel allochtonen een VBO-opleiding volgen. Hier valt met name de opleiding VBO administratie, handel en textiel op. Voor dit opleidingstype wordt, zoals gezegd, een slecht arbeidsmarktperspectief verwacht. Matige perspectieven zijn er ook voor schoolverlaters uit de richting MBO/LLW beweging en therapie. Dit matige perspectief wordt met name veroorzaakt door de hoge verwachte arbeidsmarktinstroom van schoolverlaters. In tabel 5.3 wordt aangegeven dat er ook opleidingen zijn die veel door allochtonen worden gevolgd die wel goede arbeidsmarktperspectieven hebben. Voor de allochtone jongens zijn dat met name de opleidingstypen MBO/LLW administratie, MBO/LLW elektrotechniek en MAVO. Voor de meisjes zijn dat met name de opleidingstypen $M B O / L L W$ administratie, en $M A V O$, met een goed arbeidsmarktperspectief, en het opleidingstype $M B O / L L W$ verpleging dat zelfs een zeer goed perspectief kent.

Tussen de diverse groepen allochtonen bestaan er ook vrij grote verschillen in de arbeidsmarktperspectieven van de gevolgde opleidingen (zie ROA, 1997c). De allochtonen van Marokkaanse afkomst hebben binnen de groep allochtonen relatief de slechtste arbeidsmarktperspectieven, de mensen uit voormalig Joegoslavië de beste. De steekproefomvang laat het echter niet toe dat er een tabel zoals 5.3 gegeven wordt van de verdeling van de verschillende groepen allochtonen over de diverse opleidingstypen.

In tabel 5.4 wordt een overzicht gegeven van de beroepenspreiding en de conjunctuurgevoeligheid van de werkgelegenheid van de opleidingstypen waar een groot deel van de allochtone jongeren uitstroomt. Evenals bij de meisjes in het algemeen bleek, volgen ook allochtone meisjes vaker opleidingen die minder conjunctuurgevoelig zijn dan de opleidingen die allochtone jongens volgen. Bij de allochtone jongens valt VBO bouwtechniek op als een opleidingstype met een hoog arbeidsmarktrisico: weinig uitwijkmogelijkheden naar verschillende beroepen en een hoge conjunctuurgevoeligheid van de werkgelegenheid. Bij het opleidingstype VBO verzorging daarentegen zijn arbeidsmarktrisico's daarentegen gering. Zoals gezegd, zijn met name de lange-termijn perspectieven van de VBO-opleidingen echter slecht, gezien de hoge arbeidsmarktuitstroom van werkenden op relatief jonge leeftijd. De algemene opleidingen MAVO, HAVO en VWO hebben een laag arbeidsmarktrisico: ze hebben een hoge beroepenspreiding en een gemiddelde conjunctuurgevoeligheid en een verwacht aantal baanopeningen dat ruim voldoende is de uitstroom aan 
schoolverlaters op te vangen. Daarnaast kunnen deze algemene opleidingen een goede opstap zijn voor een beroepsopleiding op MBO-niveau of hoger. In de rij van "meisjes-opleidingen" staan geen opleidingen die een erg hoog risico lijken op te leveren. Wel kent de opleiding $M B O / L L W$ verzorging een erg lage beroepenspreiding, hetgeen op termijn wel degelijk een risico in kan houden.

Tabel 5.4

Uitwijkmogelijkheden en conjunctuurgevoeligheid voor de meest voorkomende opleidingen onder allochtone jongeren, onderverdeeld naar geslacht

\begin{tabular}{lll}
\hline Opleidingstype & Beroepenspreiding & $\begin{array}{l}\text { Conjunctuur- } \\
\text { gevoeligheid }\end{array}$ \\
\hline
\end{tabular}

TOTAAL

VBO administratie, handel en textiel

HAVONWO

MBO/LLW administratie

VBO mechanische techniek

VBO verzorging

MAVO

VBO motorvoertuigentechniek

VBO bouwtechniek

MBO/LLW handel

$\mathrm{MBO} / \mathrm{LLW}$ beweging en therapie

$\begin{array}{ll}\text { hoog } & \text { gemiddeld } \\ \text { hoog } & \text { gemiddeld } \\ \text { gemiddeld } & \text { gemiddeld } \\ \text { hoog } & \text { hoog } \\ \text { hoog } & \text { laag } \\ \text { erg hoog } & \text { gemiddeld } \\ \text { gemiddeld } & \text { hoog } \\ \text { laag } & \text { erg hoog } \\ \text { hoog } & \text { gemiddeld } \\ \text { gemiddeld } & \text { gemiddeld }\end{array}$

\section{JONGENS}

VBO administratie, handel en textie

VBO mechanische techniek

VBO motorvoertuigentechniek

VBO bouwtechniek

$\mathrm{MBO} / \mathrm{LLW}$ administratie

HAVO/WWO

MBO/LLW elektrotechniek

MAVO

MBO/LLW beweging en therapie

MBO/LLW handel

$\begin{array}{ll}\text { hoog } & \text { gemiddeld } \\ \text { hoog } & \text { hoog } \\ \text { gemiddeld } & \text { hoog } \\ \text { laag } & \text { erg hoog } \\ \text { gemiddeld } & \text { gemiddeld } \\ \text { hoog } & \text { gemiddeld } \\ \text { gemiddeld } & \text { hoog } \\ \text { erg hoog } & \text { gemiddeld } \\ \text { gemiddeld } & \text { gemiddeld } \\ \text { hoog } & \text { gemiddeld }\end{array}$

\section{MEISJES}

VBO administratie, handel en textiel

HAVONWO

VBO verzorging

MBO/LLW administratie

MAVO

MBO/LLW hande

$\mathrm{MBO} / \mathrm{LLW}$ beweging en therapie

MBO sociaal-cultureel

$\mathrm{MBO} / \mathrm{LLW}$ verpleging

$\mathrm{MBO} / L L W$ verzorging

$\begin{array}{ll}\text { hoog } & \text { gemiddeld } \\ \text { hoog } & \text { gemiddeld } \\ \text { hoog } & \text { laag } \\ \text { gemiddeld } & \text { gemiddeld } \\ \text { erg hoog } & \text { gemiddeld } \\ \text { hoog } & \text { gemiddeld } \\ \text { gemiddeld } & \text { gemiddeld } \\ \text { gemiddeld } & \text { gemiddeld } \\ \text { erg laag } & \text { laag } \\ \text { gemiddeld } & \text { gemiddeld }\end{array}$

Bron ROA (1997c), RUBS 1996

\section{Beleidsimplicatie}

Op basis van de in dit hoofdstuk gepresenteerde arbeidsmarktgegevens kan geconcludeerd worden dat de arbeidsmarktpositie van allochtone schoolverlaters verbeterd kan worden door de deelname aan opleidingen op een MBO/leerlingwezen-niveau of hoger te stimuleren, teneinde de arbeidsmarktrisico's die op 
korte of lange termijn verbonden zijn aan de keuze voor een VBO-opleiding te verkleinen. Uiteraard kan er in tweede instantie dan ook gedacht worden aan een verschuiving in de richting van anders georiënteerde opleidingstypen zoals gesuggereerd bij de bespreking van de arbeidsmarktperspectieven van meisjes.

Bij vergelijking van de in de tabellen 5.1 en 5.3 voorkomende opleidingen valt op dat een groot deel van de allochtonen een VBO-opleiding volgt, waarbij de allochtonen onder de schoolverlaters van deze opleidingen ook een relatief grote groep vormen. Een voorbeeld van een dergelijke situatie is de opleiding VBO administratie, handel en textiel die door $20 \%$ van de allochtone schoolverlaters is gevolgd. Van het totaal aantal schoolverlaters van dit opleidingstype is ook weer liefst $20 \%$ van allochtone afkomst. Deze concentratie van allochtonen binnen een relatief klein aantal opleidingstypen, gecombineerd met de sterke oververtegenwoordiging van allochtonen bij deze opleidingen houdt het risico in van een tweedeling. Omdat het arbeidsmarktperspectief van deze opleidingen slecht is, is het risico des te groter wanneer allochtonen er niet in slagen na hun intrede op de arbeidsmarkt alsnog een 'startkwalificatie' te behalen door een aanvullende opleiding op MBO/LLW-niveau af te ronden.

De verschillen tussen de beide tabellen worden veroorzaakt door het feit dat er opleidingen zijn waar wel een relatief groot deel van de allochtonen naar toe gaat, maar waar binnen de opleidingen de allochtonen niet oververtegenwoordigd zijn. Voorbeelden hiervan zijn bijvoorbeeld de opleidingen MBO/LLW administratie, MAVO en HAVONWO. Omdat dit ook opleidingen zijn met een goed arbeidsmarktperspectief lijkt verhoging van de opleidingsparticipatie van allochtonen in deze richting een goede strategie om enerzijds de arbeidsmarktpositie van allochtonen te verbeteren, en anderzijds een mogelijke tweedeling tegen te gaan. Bovendien kunnen de AVO-opleidingen een goede opstap betekenen voor een beroepsopleiding op MBO-niveau of hoger. Meer in het algemeen lijkt het in het kader van verbetering van de arbeidsmarktpositie van allochtonen een goede strategie om te stimuleren dat de opleidingskeuze van de allochtonen over de diverse opleidingstypen meer overeenkomst gaat tonen met de verdeling van de autochtone schoolverlaters. 


\section{Conclusies}

In dit rapport zijn achtereenvolgens drie zaken aan de orde geweest. Ten eerste de arbeidsmarktperspectieven van meisjes, gerelateerd aan hun opleidings- en beroepskeuze. Ten tweede de mate waarin deeltijdwerk beschikbaar is voor mannen en vrouwen met een verschillende opleidingsachtergrond en beroepskeuze. Hierbij gaat het met name om de vraag in hoeverre het voor jongens mogelijk is om werk te combineren met zorgtaken in de verschillende beroepen waarin zij emplooi vinden. Ten derde zijn de arbeidsmarktperspectieven van allochtone schoolverlaters aan de orde geweest. Daarbij is de centrale vraag in hoeverre door het stimuleren van een andere studie- of beroepskeuze het gezien de arbeidsmarktperspectieven voor de komende jaren mogelijk is de arbeidsmarktpositie van de genoemde doelgroepen te verbeteren.

"Typische meisjesopleidingen en -beroepen" doen zich voor in de verzorgende en dienstverlenende richtingen. Op een paar uitzonderingen na, zijn de huidige perspectieven voor die richtingen goed. Ondanks deze goede perspectieven voor de "meisjesopleidingen" blijkt dat de arbeidsmarktperspectieven voor meisjes, gemiddeld genomen, toch iets minder goed zijn dan voor jongens. Dit verschil kan in principe op twee manieren verkleind worden. Enerzijds kan er gestimuleerd worden dat meisjes binnen de categorie "typische meisjesopleidingen" en "typische meisjesberoepen" vaker kiezen voor opleidingstypen en de beroepsgroepen met de beste perspectieven. Anderzijds zouden ze gestimuleerd kunnen worden om te kiezen voor "typische jongensopleidingen" en "-beroepen" met een goed perspectief. Als het er om gaat om opleidingen binnen de "typische jongensopleidingen" aan te geven waar mogelijk kansen liggen voor meisjes, zijn er uiteraard de technische opleidingen waarvoor de perspectieven goed tot erg goed zijn. Als nadelen voor die opleidingen geldt wel dat de huidige deelname van meisjes aan deze opleidingen laag is, dat de conjunctuurgevoeligheid van de werkgelegenheid relatief hoog is en dat bij sommige opleidingstypen de uitwijkmogelijkheden op de arbeidsmarkt relatief laag zijn. Al met al maakt dit het voor meisjes in het algemeen de komende jaren weinig aantrekkelijk om hun studiekeuze te verschuiven naar een technische opleiding. Het is moeilijk opleidingstypen aan te wijzen met goede arbeidsmarktperspectieven in combinatie met een laag structureel risico, waar meisjes geen pioniersrol hoeven te vervullen. Alleen de opleidingen $M B O / L L W$ horeca, $H B O$ recht en bestuur en WO bedrijfskunde voldoen aan alle drie deze criteria. Voor het overige worden in al deze beroepen meisjes geconfronteerd met ofwel een lage beroepenspreiding ofwel een hoge mate van conjunctuurgevoeligheid van de werkgelegenheid.

Er kan ook getracht worden meisjes te stimuleren zich te richten op opleidingen en beroepen waar meisjes en jongens in min of meer gelijke mate voorkomen of de opleidingen en beroepen die nu voornamelijk het domein zijn van jongens. Wanneer meisjes gestimuleerd worden te kiezen voor een "neutrale" opleiding met een goed perspectief, brengt dit het risico met zich mee dat juist in die opleidingen waar de 
aantallen jongens en meisjes elkaar in evenwicht houden er nieuwe "meisjesopleidingen" ontstaan. Veeleer lijkt het aan te bevelen meisjes te stimuleren te kiezen voor opleidingen waar de meisjes nu nog ondervertegenwoordigd zijn. Hierbij moet natuurlijk wel bedacht worden dat eventuele pogingen in die richting een grotere kans van slagen hebben als deze opleidingen en beroepen aansluiten bij de oriëntatie zoals de groep die nu al heeft. Uiteraard wordt de afstand tussen jongensen meisjesopleidingen en jongens- en meisjesberoepen ook verkleind door de jongens te stimuleren een meisjesopleiding of -beroep te kiezen. $\mathrm{Er}$ is de laatste jaren wel een verschuiving geweest in de arbeidsmarktoriëntatie van meisjes, die in vaker kiezen voor een "jongensopleiding", maar het omgekeerde, jongens die vaker kiezen voor een "meisjesopleiding" kan tot nu toe niet worden waargenomen. De gegevens in dit rapport laten zien dat er opleidingen en beroepen zijn waar de meisjes nu in de meerderheid zijn, die ook voor jongens een perspectiefrijk alternatief kunnen zijn.

Een tweede aspect dat in dit rapport aan de orde komt is de mate waarin de mogelijkheid tot deeltijdwerken gekoppeld is aan een bepaalde opleidingsachtergrond of beroepskeuze. Het blijkt dat dit duidelijk het geval is. De mate waarin deeltijdwerk voorkomt bij werknemers met een bepaalde opleidingsachtergrond of binnen een bepaalde beroepsgroep hangt duidelijk samen met het percentage vrouwen met de desbetreffende opleidingsachtergrond of het percentage vrouwen dat in het desbetreffende beroep werkzaam is. Dit neemt echter niet weg dat ook binnen de groep "typische jongensberoepen" er wel degelijk een stijgende tendens in het werken in deeltijd waar te nemen is. Het is wel opvallend dat er tegen de algemene trend in, ook beroepen zijn waar het percentage deeltijders daalt. Een mogelijke verklaring voor deze tendens zou kunnen zijn dat door de verbeterde arbeidsmarktsituatie meer mensen die dit ambiëren een voltijdse aanstelling kunnen krijgen. Gezien de verwachte goede arbeidsmarktperspectieven voor veel opleidingstypen zou dit de komende jaren bij meer opleidingen een rol kunnen gaan spelen.

Het derde onderwerp dat in dit rapport aan de orde is gekomen, zijn de arbeidsmarktperspectieven van de allochtone schoolverlaters. In dit rapport is een overzicht gegeven van de opleidingstypen met relatief veel schoolverlaters van allochtone afkomst. Ook is er een overzicht gegeven van de spreiding van de allochtonen over de diverse opleidingstypen. Uit beide overzichten blijkt dat veel allochtone jongeren een VBO-opleiding volgen. De jongens kiezen daarbij vaak voor een technische richting, terwijl de meisjes vaker kiezen voor administratief gerichte opleidingen. Op dit punt is er weinig verschil tussen allochtone en autochtone jongeren. Wat op termijn een veel groter risico inhoudt voor de allochtone schoolverlaters is dat een VBO-diploma op de wat langere termijn slechte perspectieven biedt op de arbeidsmarkt indien men later niet alsnog een "startkwalificatie" op MBO/LLW-niveau verwerft.

Voor het verbeteren van de arbeidsmarktpositie van allochtonen is het een goede strategie om te stimuleren dat de verdeling van de allochtonen over de diverse 
opleidingstypen meer overeenkomst gaat tonen met de opleidingsachtergronden van de autochtone schoolverlaters. Immers, een relatief groot deel van de allochtonen volgt een VBO-opleiding, en binnen deze opleidingen vormen de allochtonen een relatief grote groep. Dit houdt het gevaar in van een tweedeling, namelijk dat er in de praktijk opleidingen ontstaan zijn die uitsluitend door allochtonen gevolgd worden, terwijl slechts weinig allochtonen een andere opleidingsachtergrond hebben. Om een dergelijke tweedeling te voorkomen moeten allochtonen vooral gestimuleerd worden een opleiding op MBO/Leerlingwezen-niveau of hoger te gaan volgen. Dit is een belangrijke voorwaarde om voor de allochtone schoolverlaters een betere positie op de arbeidsmarkt te bewerkstelligen. 


\section{Enkele centrale begrippen}

- Baanopeningen: totale vraag naar nieuwkomers op de arbeidsmarkt, zoals deze is bepaald door de werkgelegenheidsgroei (positieve uitbreidingsvraag) en de vervangingsvraag.

- De conjunctuurgevoeligheid van de werkgelegenheid heeft betrekking op de mate waarin de werkgelegenheid in een beroepsklasse, of voor mensen met een bepaalde opleidingsachtergrond, gevoelig is voor veranderingen in de economische situatie. Deze indicator geeft daarmee de mate van werkzekerheid aan De conjunctuurgevoeligheid wordt bepaald door de sectorale werkgelegenheidsfluctuaties in het verleden te relateren aan de mate waarin de beroepsgroep momenteel in de verschillende bedrijfssectoren is vertegenwoordigd. Hierbij wordt rekening gehouden met het feit dat niet ieder beroep even sterk meefluctueert met de werkgelegenheidsschommelingen van de bedrijfssector.

- Indicator toekomstig arbeidsmarktperspectief (ITA): deze maatstaf is gedefinieerd als de verhouding tussen enerzijds de verwachte instroom van schoolverlaters en het aantal kortdurig passieve werklozen en anderzijds de verwachte baanopeningen en de substitutievraag. Naarmate de indicator hoger is, wordt het perspectief slechter.

- Instroom van schoolverlaters: het aanbod van nieuwe arbeidskrachten op de arbeidsmarkt, zoals deze is bepaald door de verwachte uitstroom van schoolverlaters uit het initiële dagonderwijs, de schoolverlaters van het deeltijdonderwijs, het niet-reguliere voltijdonderwijs en de beroepsgerichte volwasseneneducatie.

- Uitbreidingsvraag: de vraag naar nieuwe arbeidskrachten die ontstaat door groei van de werkgelegenheid. Als er sprake is van een werkgelegenheidsdaling, is de uitbreidingsvraag negatief.

- Uitwijkmogelijkheden: de mate waarin arbeidskrachten met een bepaalde opleidingsachtergrond of met een bepaald beroep terecht kunnen komen in andere beroepsgroepen op een aansluitend of hoger functieniveau, respectievelijk in andere bedrijfsklassen. Deze maatstaf geeft daarmee aan in hoeverre arbeidskrachten afhankelijk zijn van de arbeidsmarktsituatie in een bepaald beroep of een bepaalde bedrijfssector. De uitwijkmogelijkheden worden bepaald met een spreidingsindex. deze index geeft een indicatie van het aantal beroepsgroepen of bedrijfsklasse waarnaar men kan uitwijken.

- Vervangingsvraag: de vraag naar nieuwe arbeidskrachten die ontstaat doordat de arbeidsplaatsen van werkenden die met pensioen gaan, arbeidsongeschikt worden of zich (tijdelijk) terugtrekken van de arbeidsmarkt, opnieuw moeten worden opgevuld. De vervangingsvraag per beroepsklasse kan bovendien ontstaan door de beroepsmobiliteit. Vertrek van werkenden dat niet leidt tot 
vraag naar nieuwkomers uit hetzelfde opleidingstype of beroepsklasse, wordt niet meegerekend als vervangingsvraag. 


\section{Literatuur}

Beek, K.W.H. van (1993), To be hired or not to be hired, the employer decides: relative chances of unemployed jobs seekers on the Dutch labour market. Amsterdam.

Centraal Bureau voor de Statistiek (1997a), Sociaal Economische maandstatistiek 97/7, Voorburg/Heerlen.

Centraal Bureau voor de Statistiek (1997b), Enquête Beroepsbevolking 1996, Voorburg/Heerlen.

Researchcentrum voor Onderwijs en Arbeidsmarkt (1997a), Schoolverlaters tussen onderwijs en arbeidsmarkt 1996, ROA-R-1997/3, Maastricht.

Researchcentrum voor Onderwijs en Arbeidsmarkt (1997b), De arbeidsmarkt naar opleiding en beroep tot 2002, ROA-R-1997/7, Maastricht.

Researchcentrum voor Onderwijs en Arbeidsmarkt (1997c), Statistische bijlage, De arbeidsmarkt naar opleiding en beroep tot 2002, ROA-R-1997/7b, Maastricht. 


\section{Bijlage 1}

Totaaloverzicht van arbeidsmarktperspectieven in 2002, de beroepenspreiding (gemiddelde 1995-1996) en de conjunctuurgevoeligheid van opleidingstypen, gerangschikt naar "meisjes-", "neutrale" en "jongens-" opleidingstypen

\begin{tabular}{|c|c|c|c|}
\hline Opleidingstype & $\begin{array}{l}\text { Arbeidsmarkt- } \\
\text { perspectief }\end{array}$ & $\begin{array}{l}\text { Beroepen- } \\
\text { spreiding }\end{array}$ & $\begin{array}{l}\text { Conjunctuur- } \\
\text { gevoeligheid }\end{array}$ \\
\hline
\end{tabular}

\begin{tabular}{|c|c|c|c|}
\hline $\begin{array}{l}\text { VBO verzorging } \\
\text { MBO dokters-, tandarts- en dierenartsassistent } \\
\text { MBO/LLW apothekersassistent } \\
\text { MBO/LLW verpleging } \\
\text { MBO sociaal-cultureel } \\
\text { MBO/LLW verzorging } \\
\text { MBO/LLW uiterlijke verzorging } \\
\text { MBO/LLW beweging en therapie } \\
\text { MBO/LLW secretariaat } \\
\text { MBO/LLW toerisme en recreatie } \\
\text { HBO lerarenopleiding basisonderwijs } \\
\text { HBO lerarenopleiding medisch en verzorging } \\
\text { HBO verpleegkunde } \\
\text { HBO (fysio)therapie } \\
\text { HBO voeding } \\
\text { HBO toerisme en recreatie } \\
\text { HBO secretariaat } \\
\text { HBO bibliotheek en documentatie }\end{array}$ & $\begin{array}{l}\text { redelijk } \\
\text { matig } \\
\text { goed } \\
\text { zeer goed } \\
\text { redelijk } \\
\text { matig } \\
\text { goed } \\
\text { matig } \\
\text { goed } \\
\text { slecht } \\
\text { goed } \\
\text { goed } \\
\text { goed } \\
\text { goed } \\
\text { goed } \\
\text { redelijk } \\
\text { goed } \\
\text { goed }\end{array}$ & $\begin{array}{l}\text { hoog } \\
\text { erg laag } \\
\text { erg laag } \\
\text { erg laag } \\
\text { gemiddeld } \\
\text { erg laag } \\
\text { gemiddeld } \\
\text { laag } \\
\text { hoog } \\
\text { gemiddeld } \\
\text { erg laag } \\
\text { laag } \\
\text { erg laag } \\
\text { erg laag } \\
\text { laag } \\
\text { gemiddeld } \\
\text { hoog } \\
\text { gemiddeld }\end{array}$ & $\begin{array}{l}\text { laag } \\
\text { laag } \\
\text { laag } \\
\text { laag } \\
\text { gemiddeld } \\
\text { gemiddeld } \\
\text { gemiddeld } \\
\text { gemiddeld } \\
\text { gemiddeld } \\
\text { gemiddeld } \\
\text { gemiddeld } \\
\text { gemiddeld } \\
\text { laag } \\
\text { erg laag } \\
\text { erg laag } \\
\text { gemiddeld } \\
\text { gemiddeld } \\
\text { erg laag }\end{array}$ \\
\hline \multicolumn{4}{|l|}{ NEUTRAAL } \\
\hline $\begin{array}{l}\text { MAVO } \\
\text { VBO administratie, handel en textiel } \\
\text { HAVO/NWO } \\
\text { MBO/LLW laboratorium } \\
\text { MBO/LLW administratie } \\
\text { MBO/LLW handel } \\
\text { HBO lerarenopleiding talen } \\
\text { HBO lerarenopleiding economie en } \\
\text { maatschappij } \\
\text { HBO lerarenopleiding expressie } \\
\text { HBO tolk en vertaler } \\
\text { HBO laboratorium } \\
\text { HBO communicatie en journalistiek } \\
\text { HBO maatschappelijk werk en hulpverlening } \\
\text { HBO personeelswerk } \\
\text { HBO uitvoerende en beeldende kunsten } \\
\text { WO letteren } \\
\text { WO farmacie } \\
\text { WO rechten en bestuurskunde } \\
\text { WO sociale wetenschappen } \\
\text { WO kunstwetenschappen }\end{array}$ & $\begin{array}{l}\text { goed } \\
\text { slecht } \\
\text { redelijk } \\
\text { goed } \\
\text { goed } \\
\text { redelijk } \\
\text { goed } \\
\text { zeer goed } \\
\text { goed } \\
\text { goed } \\
\text { goed } \\
\text { goed } \\
\text { goed } \\
\text { slecht } \\
\text { goed } \\
\text { goed } \\
\text { redelijk } \\
\text { goed } \\
\text { goed } \\
\text { matig }\end{array}$ & $\begin{array}{l}\text { erg hoog } \\
\text { hoog } \\
\text { hoog } \\
\text { gemiddeld } \\
\text { gemiddeld } \\
\text { hoog } \\
\text { laag } \\
\text { hoog } \\
\text { gemiddeld } \\
\text { hoog } \\
\text { gemiddeld } \\
\text { laag } \\
\text { gemiddeld } \\
\text { laag } \\
\text { laag } \\
\text { gemiddeld } \\
\text { erg laag } \\
\text { erg laag } \\
\text { hoog } \\
\text { gemiddeld }\end{array}$ & $\begin{array}{l}\text { gemiddeld } \\
\text { gemiddeld } \\
\text { gemiddeld } \\
\text { laag } \\
\text { gemiddeld } \\
\text { gemiddeld } \\
\text { gemiddeld } \\
\text { gemiddeld } \\
\text { laag } \\
\text { erg laag } \\
\text { gemiddeld } \\
\text { gemiddeld } \\
\text { gemiddeld } \\
\text { gemiddeld } \\
\text { laag } \\
\text { laag } \\
\text { gemiddeld } \\
\text { laag } \\
\text { laag } \\
\text { laag }\end{array}$ \\
\hline \multicolumn{4}{|l|}{ JONGENS } \\
\hline $\begin{array}{l}\text { Basisonderwijs } \\
\text { VBO landbouw en natuurlijke omgeving } \\
\text { VBO bouwtechniek } \\
\text { VBO installatietechniek } \\
\text { VBO mechanische techniek } \\
\text { VBO fijnmechanische techniek } \\
\text { VBO motorvoertuigentechniek } \\
\text { VBO elektrotechniek }\end{array}$ & $\begin{array}{l}\text { matig } \\
\text { goed } \\
\text { redelijk } \\
\text { slecht } \\
\text { goed } \\
\text { goed } \\
\text { redelijk } \\
\text { goed }\end{array}$ & $\begin{array}{l}\text { erg hoog } \\
\text { gemiddeld } \\
\text { laag } \\
\text { gemiddeld } \\
\text { hoog } \\
\text { hoog } \\
\text { gemiddeld } \\
\text { hoog }\end{array}$ & $\begin{array}{l}\text { gemiddeld } \\
\text { gemiddeld } \\
\text { erg hoog } \\
\text { erg hoog } \\
\text { hoog } \\
\text { hoog } \\
\text { hoog } \\
\text { hoog }\end{array}$ \\
\hline
\end{tabular}


Bijlage 1 (vervolg)

Totaaloverzicht van arbeidsmarktperspectieven in 2002, de beroepenspreiding (gemiddelde 1995-1996) en de conjunctuurgevoeligheid van opleidingstypen, gerangschikt naar "meisjes-", "neutrale" en "jongens-" opleidingstypen

\begin{tabular}{|c|c|c|c|}
\hline Opleidingstype & $\begin{array}{l}\text { Arbeidsmarkt- } \\
\text { perspectief }\end{array}$ & $\begin{array}{l}\text { Beroepen- } \\
\text { spreiding }\end{array}$ & $\begin{array}{l}\text { Conjunctuur- } \\
\text { gevoeligheid }\end{array}$ \\
\hline $\begin{array}{l}\text { VBO grafische techniek } \\
\text { VBO brood en banket } \\
\text { VBO horeca en levensmiddelentechniek } \\
\text { VBO vervoer } \\
\text { VBO beveiliging } \\
\text { MBO/LLWW landbouw en veeteelt } \\
\text { MBO/LLWW milieu en groene ruimte } \\
\text { MBO/LLWW bouw } \\
\text { MBO/LLW grond-, weg- en waterbouw } \\
\text { MBO/LLW installatietechniek } \\
\text { MBO/LLW werktuigbouw en mechanische } \\
\text { techniek } \\
\text { MBO/LLW fijnmechanische techniek } \\
\text { MBO/LLW motorvoertuigentechniek } \\
\text { MBO/LLW vliegtuigtechniek } \\
\text { MBO/LLW operationele techniek } \\
\text { MBO/LLW elektrotechniek } \\
\text { MBO/LLW grafische techniek } \\
\text { MBO/LLW procestechniek } \\
\text { MBO/LLW brood en banket } \\
\text { MBO/LLW levensmiddelentechniek/ } \\
\text { vleesverwerking } \\
\text { MBO/LLW vervoer } \\
\text { MBO/LLW horeca } \\
\text { MBO openbare orde en veiligheid } \\
\text { HBO lerarenopleiding natuur en techniek } \\
\text { HBO lerarenopleiding lichamelijke opvoeding } \\
\text { HBO landbouw en veeteelt } \\
\text { HBO milieukunde en levensmiddelen- } \\
\text { technologie } \\
\text { HBO bouwkunde } \\
\text { HBO civiele techniek } \\
\text { HBO werktuigbouwkunde } \\
\text { HBO elektrotechniek } \\
\text { HBO informatica } \\
\text { HBO chemische technologie } \\
\text { HBO vervoer en logistiek } \\
\text { HBO accountancy en bedrijfseconomie } \\
\text { HBO commerciële economie } \\
\text { HBO recht en bestuur } \\
\text { HBO bedrijfskunde } \\
\text { HBO openbare orde en veiligheid } \\
\text { WO theologie } \\
\text { WO landbouw en milieukunde } \\
\text { WO wiskunde en natuurwetenschappen } \\
\text { WO bouwkunde } \\
\text { WO civiele techniek } \\
\text { WO werktuigbouwkunde } \\
\text { WO elektrotechniek } \\
\text { WO informatica en bestuurlijke } \\
\text { informatiekunde } \\
\text { WO (dier)geneeskunde } \\
\text { WO tandheelkunde } \\
\text { WO econom(etr)ie } \\
\text { WO bedrijfskunde } \\
\text { WO accountancy en belastingen } \\
\text { W }\end{array}$ & $\begin{array}{l}\text { goed } \\
\text { matig } \\
\text { slecht } \\
\text { goed } \\
\text { goed } \\
\text { goed } \\
\text { goed } \\
\text { goed } \\
\text { goed } \\
\text { goed } \\
\text { goed } \\
\text { goed } \\
\text { goed } \\
\text { goed } \\
\text { zeer goed } \\
\text { goed } \\
\text { matig } \\
\text { zeer goed } \\
\text { redelijk } \\
\text { goed } \\
\text { goed } \\
\text { zeer goed } \\
\text { goed } \\
\text { goed } \\
\text { goed } \\
\text { zeer goed } \\
\text { matig } \\
\text { zeer goed } \\
\text { goed } \\
\text { goed } \\
\text { goed } \\
\text { zeer goed } \\
\text { goed } \\
\text { zeer goed } \\
\text { goed } \\
\text { redelijk } \\
\text { zeer goed } \\
\text { goed } \\
\text { goed } \\
\text { goed } \\
\text { redelijk } \\
\text { goed } \\
\text { zeer goed } \\
\text { zeer goed } \\
\text { goed } \\
\text { goed } \\
\text { zeer goed } \\
\text { goed } \\
\text { zeer goed } \\
\text { goed } \\
\text { zeer goed } \\
\text { zeer goed }\end{array}$ & $\begin{array}{l}\text { gemiddeld } \\
\text { hoog } \\
\text { hoog } \\
\text { erg laag } \\
\text { laag } \\
\text { laag } \\
\text { laag } \\
\text { laag } \\
\text { gemiddeld } \\
\text { erg laag } \\
\text { gemiddeld } \\
\text { gemidddeld } \\
\text { laag } \\
\text { laag } \\
\text { laag } \\
\text { gemiddeld } \\
\text { laag } \\
\text { laag } \\
\text { gemiddeld } \\
\text { gemiddeld } \\
\text { hoog } \\
\text { gemiddeld } \\
\text { gemiddeld } \\
\text { gemiddeld } \\
\text { laag } \\
\text { gemiddeld } \\
\text { hoog } \\
\text { laag } \\
\text { gemiddeld } \\
\text { hoog } \\
\text { hoog } \\
\text { erg laag } \\
\text { hoog } \\
\text { gemiddeld } \\
\text { gemiddeld } \\
\text { gemiddeld } \\
\text { erg hoog } \\
\text { erg hoog } \\
\text { gemiddeld } \\
\text { erg laag } \\
\text { erg hoog } \\
\text { hoog } \\
\text { laag } \\
\text { gemiddeld } \\
\text { hoog } \\
\text { gemiddeld } \\
\text { laag } \\
\text { erg laag } \\
\text { erg laag } \\
\text { hoog } \\
\text { hoog } \\
\text { laag }\end{array}$ & $\begin{array}{l}\text { erg hoog } \\
\text { hoog } \\
\text { gemiddeld } \\
\text { erg hoog } \\
\text { gemiddeld } \\
\text { laag } \\
\text { laag } \\
\text { erg hoog } \\
\text { erg hoog } \\
\text { erg hoog } \\
\text { hoog } \\
\text { hoog } \\
\text { hoog } \\
\text { hoog } \\
\text { hoog } \\
\text { hoog } \\
\text { hoog } \\
\text { gemiddeld } \\
\text { laag } \\
\text { laag } \\
\text { hoog } \\
\text { gemiddeld } \\
\text { laag } \\
\text { gemiddeld } \\
\text { gemiddeld } \\
\text { laag } \\
\text { laag } \\
\text { erg hoog } \\
\text { erg hoog } \\
\text { gemiddeld } \\
\text { hoog } \\
\text { hoog } \\
\text { hoog } \\
\text { gemiddeld } \\
\text { hoog } \\
\text { hoog } \\
\text { gemiddeld } \\
\text { hoog } \\
\text { gemiddeld } \\
\text { erg laag } \\
\text { laag } \\
\text { gemidddeld } \\
\text { gemidddeld } \\
\text { gemidddeld } \\
\text { erg hoog } \\
\text { erg hoog } \\
\text { hoog } \\
\text { erg laag } \\
\text { erg laag } \\
\text { gemiddeld } \\
\text { gemiddeld } \\
\text { gemiddeld }\end{array}$ \\
\hline
\end{tabular}

